\title{
The capacity to adapt?: communities in a changing climate, environment, and economy on the northern Andaman coast of Thailand
}

\author{
Nathan J. Bennett $^{1}$, Philip Dearden ${ }^{2}$, Grant Murray $^{3}$ and Alin Kadfak ${ }^{4}$
}

\begin{abstract}
The health and productivity of marine ecosystems, habitats, and fisheries are deteriorating on the Andaman coast of Thailand. Because of their high dependence on natural resources and proximity to the ocean, coastal communities are particularly vulnerable to climate-induced changes in the marine environment. These communities must also adapt to the impacts of management interventions and conservation initiatives, including marine protected areas, which have livelihood implications. Further, communities on the Andaman coast are also experiencing a range of new economic opportunities associated in particular with tourism and agriculture. These complex and ongoing changes require integrated assessment of, and deliberate planning to increase, the adaptive capacity of communities so that they may respond to: (1) environmental degradation and fisheries declines through effective management interventions or conservation initiatives, (2) new economic opportunities to reduce dependence on fisheries, and (3) the increasing impacts of climate change. Our results are from a mixed methods study, which used surveys and interviews to examine multiple dimensions of the adaptive capacity of seven island communities near marine protected areas on the Andaman coast of Thailand. Results show that communities had low adaptive capacity with respect to environmental degradation and fisheries declines, and to management and conservation interventions, as well as uneven levels of adaptive capacity to economic opportunities. Though communities and households were experiencing the impacts of climate change, especially storm events, changing seasons and weather patterns, and erosion, they were reacting to these changes with limited knowledge of climate change per se. We recommend interventions, in the form of policies, programs, and actions, at multiple scales for increasing the adaptive capacity of Thailand's coastal communities to change. The analytical and methodological approach used for examining adaptive capacity could be easily modified and applied to other contexts and locales.
\end{abstract}

Key Words: adaptive capacity; alternative livelihoods; climate change; coastal communities; fisheries management; marine protected areas; social resilience; Thailand

\section{INTRODUCTION}

\section{Introduction and overview}

Globally, coastal communities are experiencing a broad array of socioeconomic and biophysical changes ranging from shifting economic situations and political settings to environmental degradation, fisheries declines, and climatic changes (Bennett et al. 2014a). On the Andaman coast of Thailand, the health and productivity of marine ecosystems, habitats, and fisheries are deteriorating (Juntaroshte 2005, World Bank 2006, Panjarat 2008), as a result of overfishing, destructive fishing, coastal development, and pollution (Cheung, Botengan and Cruz 2002, BOBLME 2012). This situation has repercussions for the estimated 621 fishing communities on the Andaman coast with 47,537 fishers who are dependent on fisheries and coastal resources (Panjarat 2008). Thailand's coastal communities must also adapt to the livelihood impacts of management interventions and conservation initiatives, including 26 large national marine parks (NMP; MNRE 2010). Fortunately, economic growth is bringing a range of new livelihood opportunities to communities, particularly in tourism and agriculture, which could diversify livelihoods and reduce pressure on marine resources (Ellis and Allison 2004). Coastal communities are also particularly vulnerable to climate-related changes, including rising ocean temperatures, extreme weather events, and changing seasons, as well as to increasing ocean acidification. All of these have both direct impacts on communities, e.g., infrastructure damage, erosion, and the ecosystems on which they depend, e.g., coral bleaching, mangroves retreating, as well as indirect impacts associated with resource dependent livelihoods (Marshall et al. 2010). Regional climate change projections suggest that the region will experience $>3^{0} \mathrm{C}$ increases in mean maximum and mean minimum temperatures, more warm days, an $8 \%$ increase in precipitation, more intense rainfall and monsoons in the rainy season, longer dry seasons, and an annual rise in sea level of 1-2 $\mathrm{mm}$ (Unnikrishnan and Shankar 2007, START 2010). There have also been a number of significant coral bleaching events in 1991, 1995, 1998, and again in 2010, along the Andaman coast (Phongsuwan 2011).

In this context of complexity and persistent change along with the socioeconomic and ecological importance of the marine environment, our mixed-methods study sets out to explore whether or not coastal communities along the northern Andaman Coast of Thailand are able to respond to these changes in a manner that supports positive social-ecological outcomes. Drawing on a multiscalar analysis, we examined whether or not these communities were willing and able to adapt to (1) environmental degradation or fisheries declines through the accommodation of outside management or conservation initiatives or through the development of local management or conservation responses; (2) nonfisheries economic or livelihood opportunities to reduce pressure on marine systems; and (3) climate related changes.

\footnotetext{
${ }^{1}$ Institute for Resources, Environment and Sustainability, University of British Columbia, ${ }^{2}$ Department of Geography, University of Victoria, ${ }^{3}$ Institute for Coastal Research, Vancouver Island University, ${ }^{4}$ School of Global Studies, University of Gothenburg
} 


\section{Framework for analysis of adaptive capacity}

Recent conceptualizations of adaptive capacity have roots in research and scholarship on social-ecological systems and resilience (Holling 1973, Berkes and Folke 1998, Gunderson and Holling 2002, Berkes et al. 2003), risk and vulnerability to hazards (Burton et al. 1993, Mustafa 1998, Smith 2013) and famine (Sen 1982, Swift 1989, Watts and Bohle 1993), and vulnerability and adaptation to climate change (Smithers and Smit 1997, McCarthy et al. 2001, Turner et al. 2003). A review of the development of theory in each of these areas is beyond our purview and can be found elsewhere (Adger 2006, Folke 2006, Gallopín 2006, Füssel $2007 a, b$, Engle 2011). However, definitions and several important points stemming from work on resilience and adaptive capacity deserve mentioning prior to introducing the analytical framework.

Resilience refers to the adaptability of a system to change. Resilience in both social and ecological systems is a function of "the amount of change the system can undergo and still retain the same controls on function and structure; the degree to which the system is capable of self-organization; and, the ability [of the system] to build and increase the capacity for learning and adaptation" (Resilience Alliance 2010). Importantly, resilience thinking prompts us to consider the inherent uncertainty, unpredictability, and complexity of linked social-ecological systems and, because human and natural systems are interdependent, to examine how and whether adaptive responses maintain long-term ecosystem functioning and productivity (Holling 2001, Berkes et al. 2003, Carpenter et al. 2009).

Social adaptive capacity is a measure of social resilience and the means to reduce the vulnerability of social institutions, communities, groups, or individuals to environmental, social, political, or economic changes, shocks, stresses, or trends. Marshall et al. (2010:6) refer to social adaptive capacity as "the ability to respond to challenges through learning, managing risks and impacts, developing new knowledge and devising effective approaches." Though previous research on adaptive capacity has tended to focus at a single scale or on singular stressors, it is broadly recognized that communities are experiencing multiple stressors (O'Brien and Leichenko 2000, Ommer 2007, Leichenko and O'Brien 2008, Bunce et al. 2010), and that the ability to adapt is influenced by actions at multiple scales: international, national, community, and household (Adger et al. 2005, Cinner et al. 2009). There have been a number of previous studies that have examined the adaptive capacity of coastal and fishing communities to change (Marschke and Berkes 2006, Cinner et al. 2009, Kalikoski et al. 2010, Marshall et al. 2010, Blythe 2013). These studies tend to take two approaches, i.e., some emphasize the innate ability of communities to adapt to change, whereas others focus more on analyzing a suite of indicators to determine the overall adaptive capacity of households or communities. We chose the latter approach. A limitation of the indicators-based approach to examining adaptive capacity is that it de-emphasizes past and current adaptive strategies (Smit and Wandel 2006), focusing instead on both local and external conditions and institutions that would facilitate or interfere with future adaptation to both social and ecological change. A strength of this approach is that it avoids a common pitfall of the former approach, i.e., listing short-term coping strategies that will lead to environmental degradation, poverty traps, or social-ecological traps (see Cinner 2011). The increasing complexity and rapidity of changes that are occurring may also mean that previous adaptive strategies employed by households and communities are no longer sufficient responses to maintain social-ecological resilience (Armitage and Johnson 2006).

Many indicators of social resilience or adaptive capacity can be found in the literature. Measures of adaptive capacity from various fields include livelihood diversification and mobility (Ellis 2000, Adger et al. 2002), levels of social, cultural, economic, human, and natural capital (Berkes and Folke 1998, Carney 1998, Lemos et al. 2013), institutional and governance processes and arrangements (Ostrom 1999, Armitage and Plummer 2011, Berman et al. 2012), a culture of learning (Hagmann and Chuma 2002), redundancy of function in organizations (Staber and Sydow 2002), access to resources (Scoones 1998), diversity of resource dependence (Bailey and Pomeroy 1996), supportive public policies and institutions (Kalikoski et al. 2010), leadership and resources (Hill 2013), and levels of income and social stability (O'Garra 2007). Adger (2003) argued that adaptive capacity is directly linked to social capital, which can be defined as relationships built on trust, networks, and reciprocity, and the resultant willingness and ability of groups to act collectively. Governance, civil and political rights, and literacy, Adger and Vincent (2005) showed, are linked to national adaptive capacity to climate change related events in Africa. Adaptive capacity is corelated with economic development and well-being (McCarthy et al. 2001, Brooks et al. 2005). The various components of adaptive capacity that guided our research and analysis are summarized under the four categories originally proposed by Folke et al. (2003): flexibility and diversity, capacity to organize, learning and knowledge, and access to assets (Table 1). The components of adaptive capacity utilized were chosen to reflect the ability of communities to adapt to (1) climate change, (2) alternative forms of development or livelihoods, and (3) environmental degradation and fisheries declines by maintaining ecosystem functioning and productivity. Figure 1 provides a visual heuristic of which of the components of adaptive capacity, as they are represented by the indicators in Appendix 1, enable adaptation to each of these three spheres of change.

\section{SITE DESCRIPTION AND METHODS}

We chose a multiple case study approach to seek insight into real life phenomena rather than generalizability (Yin 2009). Seven coastal fishing communities, Baan Tha Khao, Baan Koh Panyee, Baan Lions, Baan Tapae Yoi, Baan Koh Chang, Baan Moken, and Baan Koh Sin Hi, were selected along the northern Andaman coast of Thailand (Figure 2). Selection of communities was based on the following criteria: proximity within $3 \mathrm{~km}$ to a marine protected area, presence of different habitats, i.e., coral reefs, mangroves, and seagrass, existence of an assortment of ethnic groups, a range of populations, and a variety of livelihood portfolios (Table 2). These criteria were chosen to explore how contextual and cultural factors influenced adaptive capacity. All selected communities were on islands. The types of fisheries and gear varied by location. The marine protected areas were all national marine parks (NMP) under the jurisdiction of the Department of National Parks (DNP) and are technically 'notake' areas. 
Table 1. Categories and components of adaptive capacity (after Folke et al. 2003, Marschke and Berkes 2006, Cinner et al. 2009, McClanahan et al. 2009, Marshall et al. 2010).

\begin{tabular}{|c|c|}
\hline Categories & Components \\
\hline $\begin{array}{l}\text { Flexibility and } \\
\text { diversity }\end{array}$ & $\begin{array}{l}\text { Occupational mobility and attachment to } \\
\text { occupation } \\
\text { Occupational multiplicity, livelihood, and } \\
\text { income diversity } \\
\text { Dependence on natural resources and fisheries } \\
\text { Place attachment }\end{array}$ \\
\hline $\begin{array}{l}\text { Capacity to } \\
\text { organize }\end{array}$ & $\begin{array}{l}\text { Bonding social capital and networks } \\
\text { Gender relations } \\
\text { Participation in community, regional, and } \\
\text { protected area decision making } \\
\text { Local environmental institutions and social } \\
\text { norms } \\
\text { Environmental policies and agencies } \\
\text { Governance and leadership } \\
\text { Levels of corruption } \\
\text { Active risk management } \\
\text { Migration } \\
\text { Perception of risk }\end{array}$ \\
\hline $\begin{array}{l}\text { Learning and } \\
\text { knowledge }\end{array}$ & $\begin{array}{l}\text { Resource monitoring, feedback, and adaptation } \\
\text { mechanisms } \\
\text { Knowledge of climate change } \\
\text { Spaces for learning } \\
\text { Diversity of knowledges for natural resource } \\
\text { management } \\
\text { Change anticipation and response } \\
\text { Recognition of causality and human agency }\end{array}$ \\
\hline Access to assets & $\begin{array}{l}\text { Material assets } \\
\text { Infrastructure } \\
\text { Levels of education } \\
\text { Financial status and access to sources of credit } \\
\text { Bridging social capital } \\
\text { Institutional support } \\
\text { Natural capital } \\
\text { Equity and rights }\end{array}$ \\
\hline
\end{tabular}

A mixed-methods approach was employed to assess the adaptive capacity of the selected communities over a 10 -month period in 2011-2012. Fieldwork included a review of secondary documents, a series of key informant and in-depth interviews, and community household surveys to research the various components of adaptive capacity. The interview questionnaire was open-ended and guided by a series of questions focused on the general context of communities, perceived stressors, and qualitative measures of adaptive capacity, such as perceptions of current natural resource management institutions, descriptions of community governance processes, and local environmental institutions and social norms. A structured key informant interview in each community explored infrastructure items, livelihoods, marine resources harvested, natural resource management and conservation institutions, actions, mechanisms, community planning, adaptation and governance processes, and involvement with outside organizations. The surveys focused primarily on quantitative measures of adaptive capacity, such as household assets, livelihood diversity, and knowledge of climate change. More details on the specific methods and indicators used to assess each aspect and component of the adaptive capacity framework (Table 1) can be found in Appendix 1, and research instruments can be found in Bennett (2013).
Fig. 1. Contribution of components to community adaptive capacity to climate change, environmental degradation, and alternative livelihoods.

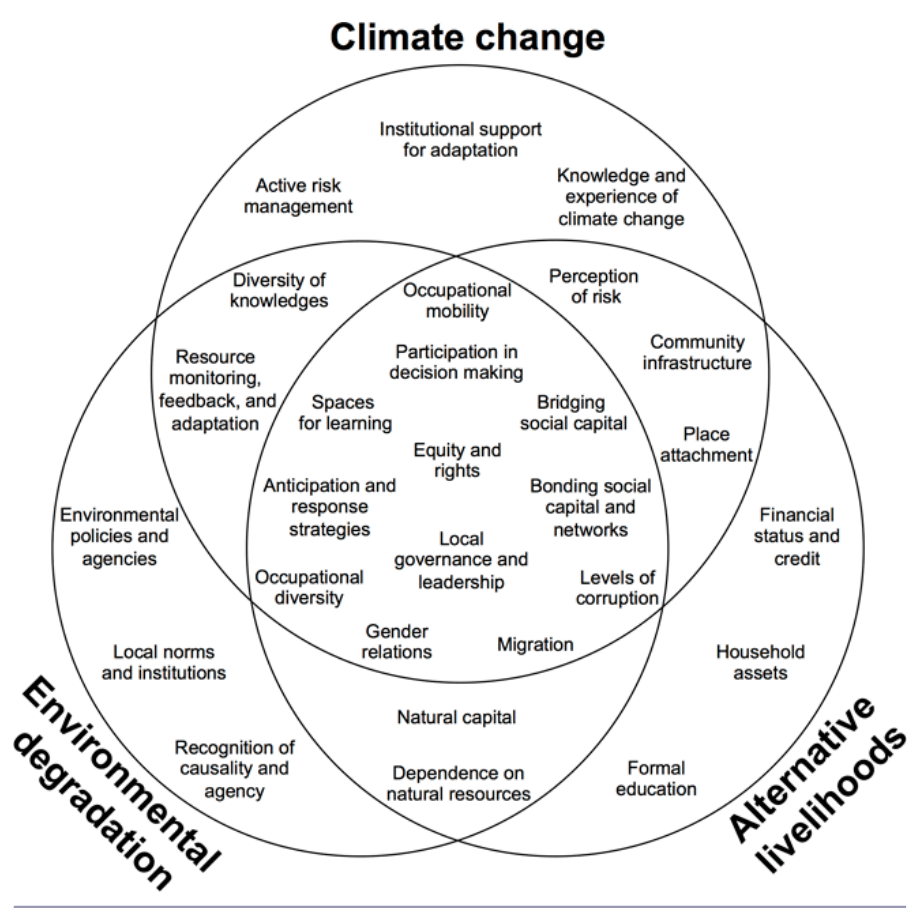

Fig. 2. Map of research sites on the Andaman coast of Thailand.

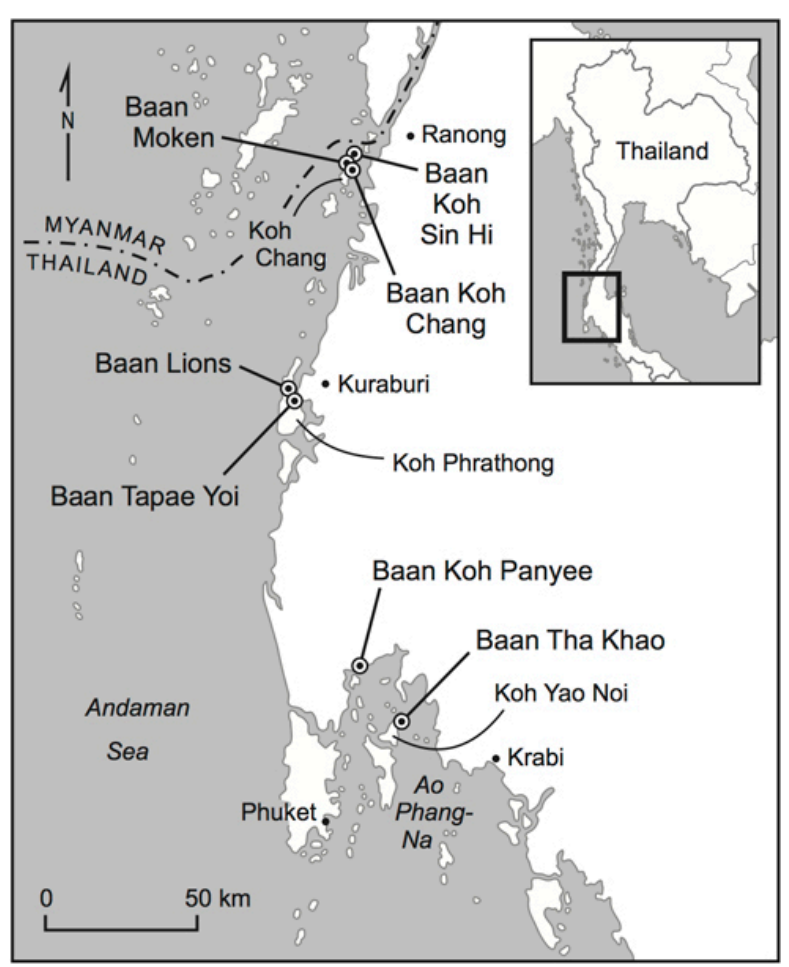


Table 2. Community information and survey sample.

\begin{tabular}{|c|c|c|c|c|c|c|c|c|c|}
\hline $\begin{array}{l}\text { Community } \\
\text { (Baan) }\end{array}$ & $\begin{array}{c}\text { National } \\
\text { Marine Park }\end{array}$ & Habitats & $\begin{array}{l}\text { Livelihoods } \\
\text { (listed by } \\
\text { importance) } \\
\end{array}$ & $\begin{array}{l}\text { Main traditional } \\
\text { fisheries }^{\dagger} \text { (gear) }\end{array}$ & $\begin{array}{l}\text { Ethnic } \\
\text { Groups }\end{array}$ & $\begin{array}{c}\text { Pop. } \\
\#\end{array}$ & $\begin{array}{l}\text { House- } \\
\text { holds \# }\end{array}$ & $\begin{array}{l}\text { Sample } \\
\#(\%)\end{array}$ & $\begin{array}{c}\text { Completed } \\
\text { Surveys \# }(\%)\end{array}$ \\
\hline Tha Khao & $\begin{array}{c}\text { Ao Phang } \\
\text { Nga and } \\
\text { Than Bhok } \\
\text { Khorani }\end{array}$ & $\begin{array}{l}\text { Coral reefs, } \\
\text { mangroves }\end{array}$ & $\begin{array}{c}\text { Rubber } \\
\text { plantations, } \\
\text { tourism, fishing, } \\
\text { gleaning }\end{array}$ & $\begin{array}{l}\text { Jack fish and reef fishes } \\
\text { (large traps), shrimp } \\
\text { (drift nets), blue crabs } \\
\text { (set nets), jellyfish (scoop } \\
\text { nets) }\end{array}$ & $\begin{array}{c}\text { Thai } \\
\text { Muslim }\end{array}$ & 486 & 142 & $47(33.1)$ & $41(28.9)$ \\
\hline Koh Panyee & $\begin{array}{c}\text { Ao Phang } \\
\text { Nga }\end{array}$ & Mangroves & $\begin{array}{l}\text { Tourism, } \\
\text { fishing, } \\
\text { aquaculture }\end{array}$ & $\begin{array}{l}\text { Shrimp (drift nets), blue } \\
\text { crabs (set nets), } \\
\text { mangrove crabs (traps, } \\
\text { hand), grouper and } \\
\text { snapper (traps, bamboo } \\
\text { stake traps), various } \\
\text { juveniles (set bag nets) }\end{array}$ & $\begin{array}{c}\text { Thai } \\
\text { Muslim }\end{array}$ & 1440 & 286 & $60(21)$ & $53(18.5)$ \\
\hline Lions & $\begin{array}{l}\text { Mu Koh } \\
\text { Rah-Koh } \\
\text { Phrathong }\end{array}$ & $\begin{array}{l}\text { Seagrass, } \\
\text { mangroves, } \\
\text { coral reefs }\end{array}$ & $\begin{array}{l}\text { Tourism, mixed } \\
\text { plantations, } \\
\text { fishing, gleaning }\end{array}$ & $\begin{array}{l}\text { Squid (traps), krill (push } \\
\text { net), mangrove crabs } \\
\text { (hand), conch and shells } \\
\text { (hand tools), sea } \\
\text { cucumber (mask and } \\
\text { compressor) }\end{array}$ & $\begin{array}{c}\text { Thai } \\
\text { Buddhist, } \\
\text { Moken }\end{array}$ & 57 & 44 & $21(47.7)$ & $15(34.1)$ \\
\hline Tapae Yoi & $\begin{array}{l}\text { Mu Koh } \\
\text { Rah-Koh } \\
\text { Phrathong }\end{array}$ & $\begin{array}{c}\text { Mangroves, } \\
\text { seagrass }\end{array}$ & $\begin{array}{l}\text { Fishing, } \\
\text { plantations, } \\
\text { tourism, } \\
\text { gleaning }\end{array}$ & $\begin{array}{l}\text { Squid (traps), krill (push } \\
\text { nets), mangrove crabs } \\
\text { (traps, hand), conch and } \\
\text { shells (hand tools), sea } \\
\text { cucumber (mask and } \\
\text { compressor), jellyfish } \\
\text { (scoop nets), grouper } \\
\text { (traps) }\end{array}$ & $\begin{array}{l}\text { Thai } \\
\text { Buddhist, } \\
\text { Moken }\end{array}$ & 119 & 63 & $22(34.9)$ & 22 (34.9) \\
\hline Koh Chang & $\begin{array}{l}\text { Mu Koh } \\
\text { Ranong }\end{array}$ & $\begin{array}{l}\text { Mangroves, } \\
\text { coral reefs }\end{array}$ & $\begin{array}{c}\text { Rubber and } \\
\text { cashew } \\
\text { plantations, } \\
\text { tourism, fishing }\end{array}$ & $\begin{array}{c}\text { Blue crab (set nets), } \\
\text { mangrove crab (hand), } \\
\text { shells (hand tools), squid } \\
\text { (traps), various fish } \\
\text { (nets) }\end{array}$ & $\begin{array}{c}\text { Thai } \\
\text { Buddhist }\end{array}$ & 300 & 126 & $39(31)$ & $31(24.6)$ \\
\hline Moken & $\begin{array}{l}\text { Mu Koh } \\
\text { Ranong }\end{array}$ & $\begin{array}{l}\text { Coral reefs, } \\
\text { mangroves }\end{array}$ & $\begin{array}{l}\text { Fishing, } \\
\text { gleaning }\end{array}$ & $\begin{array}{l}\text { Blue crab (set nets), } \\
\text { shells and sea cucumber } \\
\text { (hand tools) }\end{array}$ & Moken & 175 & 36 & $12(33.3)$ & $11(30.6)$ \\
\hline Koh Sin Hi & $\begin{array}{l}\text { Mu Koh } \\
\text { Ranong }\end{array}$ & $\begin{array}{l}\text { Mangroves, } \\
\text { seagrass, coral } \\
\text { reefs }\end{array}$ & $\begin{array}{c}\text { Fishing, } \\
\text { migration for } \\
\text { work, gleaning, } \\
\text { rubber } \\
\text { plantations }\end{array}$ & $\begin{array}{l}\text { Mackerel, silago and } \\
\text { sardinella, shrimp } \\
\text { (various nets), grouper, } \\
\text { snapper, jackfish and } \\
\text { reef fishes (small and } \\
\text { large traps), squid } \\
\text { (traps), jellyfish (scoop } \\
\text { net), shells (hand tools) }\end{array}$ & $\begin{array}{l}\text { Malay } \\
\text { Muslim, } \\
\text { Burmese }\end{array}$ & 1775 & 290 & 78 (26.9) & $64(22.1)$ \\
\hline
\end{tabular}

Notes: The fisheries listed are the main traditional fisheries that are sold through middlemen. All communities also engage in extensive multispecies subsistence fisheries. Blue crab is the generic term used to refer to open sea or bottom crabs.

Interview participants were sampled from within and outside the community using a combination of purposive and snowball samplings to privilege those who were knowledgeable or had certain affiliations. A total of 85 individual interviews were conducted with community leaders $(\mathrm{n}=22)$, community group leaders $(n=5)$, community members $(n=35)$, and government employees in the communities $(\mathrm{n}=3)$, as well as outside government $(\mathrm{n}=10)$, NGO $(\mathrm{n}=7)$, and academic $(\mathrm{n}=3)$ representatives. Government representatives who were interviewed came from the Department of National Parks, Wildlife and Plant Protection, the Department of Marine and Coastal Resources, the Ministry of Natural Resources and the Environment, the Office of Rural Development and the Department of Disaster
Prevention and Mitigation (Ministry of the Interior), and the Department of Fisheries (Ministry of Agriculture and Cooperatives). The collective orientation of the communities often resulted in convenience sampling of small groups, which led to an additional 23 small group (2-5 people) interviews with community members. The sample included 24 females, 61 males, 4 groups of women, 3 groups of men, and 16 mixed gender groups. Key informant interviews were conducted with eight male community 'gate-keepers' who were all somehow leaders in their communities. Interviews were conducted with trained local research assistants and in the local dialect. Interviews were translated while they were being conducted and field notes were taken. Interview and field notes were later transcribed and 
imported into NVivo 10 qualitative research software for analysis (QSR International 2012). Qualitative data were coded against indicators related to components of the adaptive capacity framework (Appendix 1).

A random sample of households was selected from each community to participate in the survey (Table 2). Between $21-47.7 \%$ of households in each community were sampled by selecting every $\mathrm{n}^{\text {th }}$ house from hand-drawn community maps. In total, 237 of 280 selected households were surveyed with a completion rate of $85 \%$. Survey participants had a mean age of 42.1 years and were $59.1 \%$ female. Survey assistants were trained to ensure that a standardized approach was taken when administering the survey. Survey data were uploaded into SAS quantitative research software in which additional queries were run and then exported to SPSS 21 for final analysis (SAS Institute 2012, IBM 2012). We relied on descriptive analysis of the survey data.

Several methodological and sampling limitations should be recognized: (1) potential inaccuracies related to language and cultural translations; (2) a gender bias in the interviews toward male participants and in surveys toward females; (3) sampling of communities for insight limits the generalizability of results; and, (4) results were not verified with communities as analysis was done after returning from field research. Determining the relative levels of fisheries decline or environmental degradation across the sites was beyond the scope of the current research. Limitations of the analytical approach were discussed previously.

\section{RESULTS}

Adapting to environmental degradation and fisheries declines?

Both interview and survey participants discussed environmental degradation and fisheries declines at length. Across all of the communities, interviewees consistently commented that fish were not as large as they had been in the past, that fishers and gleaners could not harvest as much as they did in the past, and that some species had disappeared altogether. Eighty seven percent $(87 \%)$ of survey respondents felt that marine resources and the number of fish in the sea had decreased. There were several possible adaptive responses that might increase the health and resilience of the marine environment and fisheries yields for local communities. First, effective fisheries regulations established by the Thai Department of Fisheries (DoF) might allow for the sustainable management of fisheries. Second, the creation of large-scale no-take marine protected areas by the Thai Department of National Parks (DNP) could support the preservation of habitats, including coral reefs, mangroves, and sea grass areas, and thus lead to fisheries increases (Halpern et al. 2009, Lester et al. 2009). For the first two interventions to be effective, communities would need to be both willing and able to adapt to these management and conservation interventions initiated through external 'environmental policies and agencies.' (Hereafter, single quotations around terms refer to components of the adaptive capacity framework in Table 1 and Appendix 1). Finally, communities might adapt to environmental declines through the development of 'local institutions and social norms, resource monitoring, and feedback mechanisms' and 'spaces for learning' to sustainably manage local resources (Ostrom 1990, 1992, Charles 2001, Hauzer et al. 2013).
Overall, it appeared that fishers in most of the research communities tended to follow the Department of Fisheries (DoF) gear restrictions of which they were aware, but fishers admittedly did not follow regulations related to species restrictions, size restrictions, or areal or seasonal closures. Interview participants told us that locals followed gear restrictions, for example, on mesh size restrictions in nets and traps and on the use of illegal gear such as push nets and dynamite. Additionally, the gear used, apparent as fishing gear even if illegal, was left lying openly around the village, in boats, or at piers. There were several exceptions: in Koh Panyee several types of illegal gear, including pongpang nets, i.e., set bag nets, were used in the mangrove canals, and bay closing nets with 'mosquito net' mesh were used for miles along the mangroves; and in Koh Sin Hi, some fishers used anchovy nets (approx. $1.5 \mathrm{~cm}$ mesh) for fishing other species. However, there was sometimes a lack of knowledge of the specific rules for each gear type. For example, the mesh sizes for grouper and snapper traps were too small in Baan Tapae Yoi and Baan Koh Panyee. Fishers claimed that this was not illegal and justified the smaller mesh size and the collection of juveniles for the purpose of fattening them in fish cage aquaculture. Though participants told us that there had been a decline in the use of illegal gear by locals, in all of the communities, participants suggested that 'outsiders' were using the illegal gear, and that commercial fishers were entering inshore waters, within $3000 \mathrm{~m}$. There was agreement among all interview participants that the DoF did not effectively or equitably enforce the rules for these intrusions. Fishers suggested several reasons why DoF was not able to enforce the rules: lack of capacity, i.e., staff and boats, lack of political will, the danger of apprehending commercial boats, and the corrupt relationships between government officials and the fishing industry. Interviews and observations showed that fishers did not follow fisheries regulations and recommendations to not catch species at certain life stages, e.g., juveniles or during spawning season. As an example, the spawning season closure measure in Ao Phang Nga was ignored by fishers in Baan Thao Khao and Baan Koh Panyee (Panjarat and Bennett 2012). Because crabs with eggs were a prized-commodity, which fetched a higher market price and participants felt they were more delicious, fishers admitted to not releasing them.

Across all of the research sites except Koh Chang, fishers appeared either (1) unwilling or unable to adapt to the presence of the national park or, (2) ignorant of the presence of or regulations associated with the marine portion of the national park. Results suggest that there are three reasons why this might be: (1) perceived negative livelihood and community impacts; (2) shortcomings of management and/or (3) the ineffective functioning of governance (Bennett and Dearden 2014). Participants consistently discussed how the presence of a national park interfered with the livelihoods of local people, particularly with fisheries but also with agriculture and plantations. A commonly expressed sentiment was that: "The national park does not allow people to make a living from the sea" (interview participant). Most participants felt that it was unjust that local, impoverished, and small-scale fishers were not allowed to fish within the NMPs. Fishers and gleaners, people who collect seafood by walking and gathering, discussed how they had no other options. Tourism opportunities were rarely seen to be related to the presence of a national park. 
Several significant management shortcomings appear to be contributing to the lack of support or the lack of knowledge. First, the NMPs were created in a top-down fashion with limited or no participation during their creation (Prasertcharoensuk et al. 2010). Second, there were and are extremely limited programs of outreach, education, and awareness building. None of the communities that we worked with had ever had a visit from DNP staff for this purpose. This meant there was a lack of knowledge about boundaries, regulations, the rationale for NMP establishment, and even their existence. A third management shortcoming is a lack of capacity to manage the area, in terms of finances, infrastructure, skills, knowledge, and leadership. A final management shortcoming is acrimonious relationships caused by minimal community 'participation in protected area decision making' and management, despite the presence of guarantees for community participation in natural resource management since the 1997 implementation of the Thai Constitution (Government of Thailand 2007a, Knight et al. 2010). In terms of governance, interview participants from all groups, i.e., government agencies, NGOs, ENGOs, academia, and communities, felt that the DNP was neither transparent nor adaptable and that it enabled corruption. These factors led to a lack of trust in the agency and NMPs and widespread unwillingness to participate in or support DNP-led marine conservation (Bennett and Dearden 2014).

Finally, though many NGOs and fisheries organizations in Thailand are contending that communities should have the right to manage their own resources (IUCN 2012), effective local environmental management would require both a conservation ethic, i.e., 'norms,' as well as the presence of 'local institutions.' We considered a conservation ethic to be strong if there were strong and consistent expressions of support for conservation actions by interview participants in communities. There appeared to be a strong conservation ethic in Lions, Tapae Yoi, Tha Khao, and Koh Chang, which resulted from either the ongoing presence of outside conservation organizations, strong local leadership, or local spiritual leaders who encouraged moderation. These four communities had local community-based conservation groups that were mainly focused on the terrestrial environment or mangroves. In Koh Panyee, there were mixed expressions of support for conservation. There seemed to be less of a conservation ethic in both Baan Moken and Koh Sin Hi. This may have been because of limited 'access to assets,' for example, lower 'financial status' or a lack of Thai citizenship, and thus 'rights' to the resource and sense of ownership, in these communities. Several (non-Moken) participants conjectured that the Moken were traditionally nomadic and would move when resources were scarce or overutilized, so culturally there had been no need to develop a conservation ethic or management practices prior to becoming settled.

Though some communities appeared to have stronger conservation ethics than others, there was still a paucity of locally developed 'environmental institutions,' including formalized regulations, processes, mechanisms, and organizations that would allow for the conservation of marine resources. In all of the communities, key informants were asked about the presence of the following institutions: gear restrictions, spatial restrictions, community mangrove forests, species restrictions, catch restrictions, temporal restrictions, resource monitoring mechanisms, enforcement of rules, and formalized spaces for sharing (Table 3). There were no species restrictions, catch restrictions, temporal restrictions, or resource monitoring mechanisms in any of the sites. In Tha Khao, Tapae Yoi, and Lions, there were what was perceived to be "locally created" gear restrictions on bay closing nets and boat-towed shell dredges, but these restrictions were consistent with national regulations. There were several small seagrass MPAs, for conch and sea cucumbers, that had been recently created in Baan Lions and Baan Tapae Yoi, but it appeared that many of the prerequisites for functioning local MPAs, e.g., adequate consultation, community consensus, means for enforcement, exclusion rights (White et al. 2006, Bennett and Dearden 2012), were not in place to ensure their longterm sustainability. Strong leadership and community spirit in Tapae Yoi may have helped to overcome the other shortcomings. There was a small coral reef MPA in Baan Tha Khao that had been abandoned, but the community did have a community mangrove forest that appeared to be functioning.

Table 3. Presence or absence of local institutions to support conservation across the research sites.

\begin{tabular}{lccccccc}
\hline \hline $\begin{array}{l}\text { Type of } \\
\text { Institution }\end{array}$ & \multicolumn{7}{c}{ Community } \\
\cline { 2 - 7 } & $\begin{array}{c}\text { Tha } \\
\text { Khao }\end{array}$ & $\begin{array}{c}\text { Koh } \\
\text { Panyee }\end{array}$ & Lions & $\begin{array}{c}\text { Tapae } \\
\text { Yoi }\end{array}$ & $\begin{array}{c}\text { Koh } \\
\text { Chang }\end{array}$ & Moken & Koh \\
Sin Hi
\end{tabular}

Notes: $\mathrm{X}=$ not present, $\sqrt{ }=$ present, $-=$ marginal presence; ${ }^{\dagger}$ none other than those already required by national law

Local enforcement of rules was only done in two communities. In Tha Khao, it was done through public shaming and confiscation of gear, which by all accounts was deemed effective. In Baan Lions, the chief suggested that he arrested people in a public meeting but others said that he had no right to do this. None of the communities had functioning small-scale fishery associations or organizations, or other 'spaces for learning' specifically dedicated to sharing and discussing actions for fisheries management or marine conservation. However, conservation actions and fisheries rules were sometimes discussed during other community meetings, and there was an outside NGO 
Table 4. Importance of fisheries-based livelihoods to households (hh) for income, employment, and subsistence.

\begin{tabular}{|c|c|c|c|c|c|c|c|c|c|}
\hline \multirow[t]{2}{*}{ Indicator } & \multicolumn{7}{|c|}{ Community } & \multirow[b]{2}{*}{ All Sites } & \multirow[b]{2}{*}{$\mathrm{p}$-value } \\
\hline & Tha Khao & $\begin{array}{c}\text { Koh } \\
\text { Panyee }\end{array}$ & Lions & Tapae Yoi & $\begin{array}{c}\text { Koh } \\
\text { Chang }\end{array}$ & Moken & $\begin{array}{c}\text { Koh Sin } \\
\mathrm{Hi}\end{array}$ & & \\
\hline $\begin{array}{l}\% \text { of households for which } \\
\text { fisheries is most important } \\
\text { livelihood for income }\end{array}$ & 10 & 9 & 7 & 68 & 10 & 82 & 73 & 35 & $<0.0001^{\ddagger}$ \\
\hline $\begin{array}{l}\text { All households mean } \\
\text { income from fisheries in } \\
\text { Thai baht }{ }^{\S} \text { (median) }\end{array}$ & $36726(0)$ & $15943(0)$ & $31120(0)$ & $\begin{array}{c}62004 \\
(58000)\end{array}$ & $17290(0)$ & $\begin{array}{c}77401 \\
(61520)\end{array}$ & $\begin{array}{c}57271 \\
(42800)\end{array}$ & $\begin{array}{r}38964 \\
(7600)\end{array}$ & $0.0003^{*}$ \\
\hline $\begin{array}{l}\text { All households mean } \\
\text { income from all sources in } \\
\text { Thai baht }{ }^{\S} \text { (median) }\end{array}$ & $\begin{array}{c}237893 \\
(216400)\end{array}$ & $\begin{array}{c}314611 \\
(240000)\end{array}$ & $\begin{array}{c}150781 \\
(157600)\end{array}$ & $\begin{array}{c}200183 \\
(122100)\end{array}$ & $\begin{array}{c}237955 \\
(200000)\end{array}$ & $\begin{array}{c}92750 \\
(76800)\end{array}$ & $\begin{array}{r}107757 \\
(78600)\end{array}$ & $\begin{array}{c}204165 \\
(152000)\end{array}$ & $<0.0001^{\ddagger}$ \\
\hline $\begin{array}{l}\% \text { of households with } 1 \text { or } \\
\text { more person with fishing as } \\
\text { primary livelihood }\end{array}$ & 63 & 21 & 40 & 78 & 16 & 82 & 88 & 55 & $<0.0001^{\ddagger}$ \\
\hline $\begin{array}{l}\% \text { of households with } 1 \text { or } \\
\text { more person with fishing as } \\
\text { secondary livelihood }\end{array}$ & 29 & 23 & 67 & 82 & 61 & 91 & 50 & 47 & $<0.0001^{\ddagger}$ \\
\hline $\begin{array}{l}\% \text { of households that } \\
\text { gather seafood for } \\
\text { subsistence }\end{array}$ & 44 & 17 & 67 & 86 & 55 & 82 & 47 & 47 & $<0.0001^{\ddagger}$ \\
\hline $\begin{array}{l}\% \text { of households that eat } \\
\text { seafood } 5 \text { or more nights } \\
\text { per week }\end{array}$ & 88 & 93 & 47 & 45 & 58 & 64 & 69 & 72 & $<0.0001^{\ddagger}$ \\
\hline
\end{tabular}

Note: ${ }^{\ddagger}$ ANOVA; ${ }^{\S} 1$ Thai baht $=$ approx. 0.031 USD

on Koh Phrathong (Lions and Tapae Yoi), which was facilitating conversations about conservation in the area.

Interview participants suggested that three factors, (1) the lack of legislation or policies to allow communities to conserve or manage their own resources, (2) a history of top-down natural resource management in Thailand, and (3) the open access regime, were all 'environmental policies' that were somewhat responsible for preventing locals from developing their own institutions. Ongoing and unresolved conflicts, e.g., between small-scale fishers and commercial fishers, were also disenfranchising local communities. Finally, all of these communities had short histories of less than 100 years, and our analysis suggests that traditional ecological knowledge, or 'diversity of knowledges' for NRM, was limited and focused primarily on accessing resources to increase harvests.

\section{Adapting to economic opportunity?}

'Occupational multiplicity and livelihood diversity' and levels of 'dependence on marine resources' in the sampled communities were quite different (Table 4). Interview participants in all of the communities noted a general decline in fisheries-based livelihoods and in fisheries yields. However, fishing for income or subsistence still maintained an important place in most households. Overall, $35.4 \%$ of households across all sites (range $=6.7 \%-81.8 \%$ ) listed fisheries livelihoods as most important in terms of income. Sampled communities were becoming increasingly dependent on other livelihoods, including tourism $(22.8 \%)$, agriculture and plantations (11.8\%), and other livelihoods (19.8\%) as the primary source of income. However, a portfolio of livelihoods made up the overall income of most households. Even with households in which fisheries were not the most significant source of income, there were often individuals whose primary (55\% of households) or secondary occupation ( $47 \%$ of households) was fisheries. Many households relied heavily on the marine environment for subsistence use (47\% of households) with $72.1 \%$ of households eating seafood five or more nights per week.

In some communities, interviewees suggested that high demand and favorable market prices meant that tourism and rubber plantations were largely responsible for raising both the average incomes of households and the overall wealth of communities, though this wealth was often highly concentrated among a few individuals who owned lots of land or tourism businesses ('equity'). The majority of livelihood opportunities were also highly 'seasonal' and income was lower in the rainy season (mean $=14,001$ Thai baht) than in dry season (mean $=23,037$ Thai baht). Males, all in household $>18$ years, had almost double the mean annual income than women, all in household $>18$ years, higher income than women on average (Male mean annual salary = 63657 Thai baht; Female mean annual salary $=34393$ Thai baht). However, women made important contributions to households through subsistence activities including gleaning, household gardening, raising livestock, and selling food and desserts. Interview participants in most of the communities felt that their income, i.e., 'financial status,' was improving, with the exception of Baan Ko Sin Hi, but livelihood and household costs were also increasing along with household debt. This meant that $38 \%$ of households felt that household income was less than expenses (38\% income equal to expenses; $24 \%$ income greater than expenses). Many survey participants believed that there were plenty of opportunities for 'occupational mobility' if they could not make a living, indicating they would choose to migrate elsewhere for work temporarily $(32.1 \%)$ or permanently $(8.9 \%)$. Of all households sampled, 19.8\% (range 9.1\%-45.5\%) received remittances from family members working elsewhere with average monthly remittances contributing significantly to household income $($ mean $=3361$ Thai baht $/$ month $)$. 
Table 5. Do people in your household own land suitable for agriculture or tourism livelihoods ( $\%$ of households).

\begin{tabular}{|c|c|c|c|c|c|c|c|c|c|}
\hline \multirow[t]{2}{*}{ Response } & \multicolumn{7}{|c|}{ Community } & \multirow[b]{2}{*}{ All Sites } & \multirow[b]{2}{*}{ p-value } \\
\hline & Tha Khao & $\begin{array}{c}\text { Koh } \\
\text { Panyee }\end{array}$ & Lions & Tapae Yoi & Koh Chang & Moken & Koh $\mathrm{Sin} \mathrm{Hi}$ & & \\
\hline$\overline{\text { Yes }}$ & 68.3 & 41.5 & 53.3 & 54.5 & 87.1 & 36.4 & 35.9 & 52.3 & $0.0005^{*}$ \\
\hline No & 31.7 & 58.5 & 46.7 & 45.5 & 9.7 & 63.6 & 62.5 & 46.8 & \\
\hline $\begin{array}{l}\text { \# of rai }{ }^{\dagger} \text { owned - mean } \\
(\text { median) }\end{array}$ & $11.7(8.5)$ & $\begin{array}{l}4.3 \\
(1.0)\end{array}$ & $39.5(18.5)$ & $21.9(10.0)$ & $51.1(48.0)$ & $\begin{array}{l}4.0 \\
(4.0)\end{array}$ & $\begin{array}{l}9.2 \\
(7.0)\end{array}$ & $\begin{array}{c}20.9 \\
(10.0)\end{array}$ & $<0.0001^{* *}$ \\
\hline
\end{tabular}

Note: ${ }^{\dagger} 1$ Thai rai $=0.4$ acres or 0.16 hectares; ${ }^{*}$ houses indicating "yes" only; ${ }^{*}=$ Chi-square; ${ }^{* *}=$ ANOVA

The extent to which communities were engaging with alternative livelihoods appeared to be largely dependent on three main factors: (1) suitability of the site for tourism, i.e., 'natural capital, ' (2) access to land and local ownership of land for livelihood purposes, i.e., 'natural capital/material assets,' and (3) hiring of locals versus outside laborers, i.e., 'bonding social capital.' Many of the communities surveyed, Tha Khao, Koh Panyee, Lions, Tapae Yoi, and Koh Chang, are situated near areas that are attractive to tourists or are themselves the home of an important tourist attraction, which allowed for tourism to flourish. However, many fishing villages on the Andaman coast are situated in mangrove forests with no access to beaches and as such are less attractive to tourists.

Land access and ownership in some communities has allowed local people to establish plantations or build bungalows. Two communities, Koh Panyee and Baan Moken, did not have easy access to land for geographical reasons and therefore could not diversify their livelihoods by establishing agricultural areas or plantations. More than half $(52.3 \%)$ of all households in all communities owned land for livelihood purposes, but it was not evenly distributed (Table 5). Local ownership was strongest in Koh Chang and Tha Khao where the majority of plantations and tourism businesses were locally owned. In all sites, but particularly in Lions, Tapae Yoi, and Koh Sin Hi, land ownership was complicated by the citizenship rights (or lack thereof) of community members, lack of clarity of land title, sales of land to outside investors, illegal encroachment, and corruption.

Finally, the hiring of labor, both Burmese and Thais, for plantations, tourism, and even to operate small-scale fishing boats from outside the community, reduced the number of opportunities available to locals and lowered wages. This problem was particularly apparent in Tha Khao, but was on the increase in Koh Panyee, Tapae Yoi, and Koh Chang. Low tourism suitability, little access or local ownership, and outside hiring all placed locals in a position in which either fisheries or outmigration were the most likely options when livelihoods faltered.

In addition to demand and markets, a number of factors acted as bridges or barriers to the ability of these communities and households to adapt. Several bridging factors consistently supported adaptation of livelihoods across our research sites, including access to various 'sources of credit,' the presence of benevolent middlemen, i.e., 'bonding social capital,' who gave loans and supported people during difficult periods, and positive perceptions of 'equity' within the community. Participants felt that 'levels of education' were increasing significantly from the previous generation, and many households had members that were attending school elsewhere. Educated youth were starting to return to work in and help their communities. The expansion of tourism and plantations was increasing the 'livelihood and income diversity' for women. Households also exhibited 'livelihood diversity' and individuals demonstrated 'flexibility.' For example, survey participants had held an average of 2.3 occupations during the past 10 years, and households had an average of 5.9 different livelihoods out of a list of 30 .

Community perceptions of the quality of 'leadership and governance' were quite varied from community to community, as were the processes used to make decisions and the 'equitable' consideration of different socioeconomic, racial groups, and genders within the community. Governance structures in some communities were inclusive of women, whereas in others they were either poorly represented or not represented at all. 'Gender relations' appeared to contribute to the amount of consideration given to women's livelihoods. The quality of 'bridging social capital' was quite mixed, with several communities having good relationships with outside private sector organizations, and only one community having an ongoing partnership with outside researchers. Many researchers had come to these communities but never returned with results. 'Bonding social capital,' or the quality of relationships within the community, varied among sites and may have been related to levels of equity. When it was too strong, 'bonding social capital' had the potential to undermine the flexibility of individuals and households within the community, as was discussed by participants in Koh Panyee. Neither 'rights' nor 'infrastructure' were evenly distributed between the communities. The absence of individual citizenship and thus 'rights,' i.e., no Thai ID card or Thai ID card with 0 , for many community members in Baan Moken and Baan Koh Sin Hi undermined flexibility. The level and quality of 'infrastructure' also varied substantially by community.

'Institutional supports,' e.g., government livelihood workshops, NGO development programs, were more likely to be found in communities that were easier to access or that were more pleasant to visit than in those communities most in need of these programs. More marginalized interview participants, i.e., by poverty, power, or ethnicity, discussed how assistance was often captured by powerful or wealthy members of the community ('equity') and that 'corruption' often interfered with the distribution of development aid or programs. A frequently discussed example was the distribution of post-tsunami aid. Finally, the success of externally sponsored projects depended on the longevity of 
project support, e.g., community-based tourism in Ban Lions, as well as ongoing support by local leaders, e.g., women's cooperative in Baan Tha Khao. During the previous decade, a significant number of diverse community savings and community development funds had been promoted and developed in this region and in Thailand, e.g., One Tambon One Million, DoF Fishing Development Fund, and Post-tsunami development funds. These had the potential to support households in adapting their livelihoods. However, the results of these funds varied between communities, depending on the local 'leadership's' capacity to manage the fund and on the impacts of 'bonding social capital' on their success.

The sampled communities were highly heterogeneous and there were quite varied capacities to adapt to alternative nonfisheries livelihoods. This produced mixed levels of livelihood diversity among households and communities. Levels of reliance on marine resources for livelihoods or subsistence were related to an array of factors primarily associated with access to assets, i.e., 'natural capital, material assets (especially land), financial status and sources of credit, education, infrastructure, social capital, and equity,' and also with the capacity to organize, i.e., 'governance and leadership, corruption, gender relations and bonding social capital.' Results also suggested that the following factors may have been interfering with the ability to adapt to nonfisheries livelihood opportunities across all of the sites: perceived or real 'corruption' in midlevel 'governance' structures, especially Tambon Administration Offices, inequitable distribution of wealth and land within communities ('equity'), rising economic costs for livelihood and household expenses and increasing levels of debt ('financial status'). We found declining 'livelihood diversity' in several communities, which tended to focus on one resource and to abandon all other livelihood opportunities, e.g., only rubber plantations or tourism.

\section{Adapting to climate change?}

Community, household, and individual adaptation to climate change is facilitated by the extent to which local people are 'experiencing climate change,' are 'knowledgeable about climate change,' and are able to change their behavior to 'actively manage risks' (Bennett et al. 2014a). Climate change adaptation can also be supported by broader-scale 'institutional supports' from national and international governmental and nongovernmental organizations.

Communities and households were clearly 'experiencing climate change' on a daily basis. According to interview and survey results, the types of climate change events most communities were experiencing were (1) more powerful and frequent storms, (2) changing seasons and rainfall patterns, e.g., less defined rainy and dry seasons, shorter rainy seasons, unseasonal rains, and more intense rains, (3) flooding, (4) rising sea levels, and (5) erosion. To a lesser degree communities were also noticing increased saltwater intrusion, increased freshwater in mangrove areas, as well as coral bleaching. Some survey participants discussed how these perceived changes would have an impact on tourism visitation, the ability to take fishing boats out, human health, and agricultural productivity.

Though local people were experiencing the effects of climate change, 'knowledge of climate change,' including what it is, why it is happening, and its impacts, was very limited among both interview and survey participants. A general lack of knowledge of climate change, as well as economic factors, situational factors, and individual values meant that individuals and households were most likely to be reacting to, rather than 'actively managing risks' or even proactively planning for, climate change. For example, of 286 houses in Koh Panyee only 10 houses did not flood during particularly high tides in recent years, yet few houses have raised their floors. The low probability of adaptation is likely partially because of limitations placed on households and individuals by economic factors, e.g., rising costs, persistent debts, and poverty; situational factors, e.g., need to watch boats, rights; and cultural and individual values, e.g., enjoying life near the ocean, quality of life, and not wanting debt. Some of these factors may interact and cause additional stress for individuals and households and may mean that they take additional risks (see Ommer 2007, Tuler et al. 2008). For example, one interviewee explained how economic stressors caused fishers to take risks: "In Koh $\mathrm{Sin} \mathrm{Hi}$, due to poverty, even though there is a lot of change and storms, we have to go out [fishing] every day even with a big storm" and, "Normally, one boat has to go out, three fishermen together. The boat owner usually hired two laborers to work on the boat but now they cannot afford to hire laborers." Interview participants also suggested that some groups, for example the Moken in Ban Moken or Tapae Yoi or less educated fishermen on Koh Sin $\mathrm{Hi}$, are less able or accustomed to thinking about and planning for the future: "these problems seem far off, uncontrollable... In Tapae Yoi, people live day to day."

Overall, interviews and surveys revealed limited 'knowledge of the impacts of climate change' or ocean acidification on habitats, species, or fisheries, although there were some interesting observations about the potential impacts of storms, sea temperatures, and degraded reefs on fish abundance. This lack of awareness is concerning because climate change and acidification are predicted to have increasingly deleterious impacts on habitats, particularly coral reefs and on fish distribution, interactions, abundance, and size and to interfere with the growth of marine species with exoskeletons or shells made of calcium carbonate (Harley et al. 2006, Hoegh-Guldberg et al. 2007, Parry et al. 2007, Guinotte and Fabry 2008, Brierley and Kingsford 2009). These long-term outcomes will have serious consequences for local fisheries livelihoods. However, very few of these communities take a collective approach or proactive stance in planning for changes in livelihoods, particularly because climate change or ocean acidification might have an impact on them. There are, however, several smaller community-based organizations that facilitate livelihoods, including the community-based tourism initiative in Lions, a tourism association on Koh Chang, a small chicken farm on Koh Sin Hi, and a women's cooperative in Tha Khao.

Although most households do not seem to plan specifically for climate change impacts, households employ other 'risk management' strategies including saving money, contributing to community savings funds, purchasing health insurance, moving to more lucrative livelihoods, supporting the education of young family members, diversifying livelihoods, participating in subsistence activities, and participating in activities of the sufficiency economy, e.g., planting household gardens and raising livestock, as proposed by the King of Thailand (Sathirathai and Piboolsravut 2004). However, overall levels of participation in many of these activities varied significantly between households and communities. 
At the community level, the main areas of focus for adaptation planning for climate change would be (1) planning community infrastructure, particularly for extreme weather events, erosion, flooding, and to ensure a supply of freshwater, (2) adapting for impacts on livelihoods, and (3) preparing for disasters. At this level too, responses to climate change trends and events tended to be reactive rather than proactive ('active risk management'). For example, erosion is a significant problem in all communities. However, there is ongoing removal of natural barriers, e.g., mangroves in front of communities, which has increased erosion and led a few communities to discuss creating concrete walls to stop erosion.

A first challenge at the community level is a lack of 'knowledge of climate change' and an ignorance of its potential future impacts among leaders in communities and regional Tambon Administration Offices. There have been several brief disaster preparedness workshops and programs organized by NGOs, e.g., Thai Red Cross in Koh Chang and Koh Sin Hi and Raks Thai in Koh Panyee, in some communities during which climate change was discussed ('institutional supports'). As a result of these workshops, postdisaster evacuation plans are in place in three communities but not in the others. Generally speaking there is almost a complete lack of government or civil society organizations that work with these communities on climate change education or adaptation. Current 'infrastructure' is built in an uncoordinated fashion by various organizations, including government agencies, local governments, Royal Foundations, and NGOs, without consideration of current or future impacts of climate change. For example, piers in Baan Lions, Tapae Yoi, and Baan Tha Khao have been rendered almost useless by erosion, and rising seawater washes over the walkways in Koh Panyee and Koh Sin Hi, whereas it did not when they were built. The effective planning and building of infrastructure in these communities is significantly limited by several factors: lack of coordination between community leaders and other organizations to ensure structures are appropriately designed and local knowledge is considered ('bridging social capital' and 'participation in decision making'), the potential for corrupt officials and businesspeople or certain community factions to siphon off financing ('corruption' and 'equity'), and limited access to financing to support locally developed infrastructure adaptation projects, such as building piers, breakwaters, elevated sidewalks, and water reservoirs ('institutional supports').

At the national level, an increasing number of structures and policies are in place to support adaptation, but coordination and implementation are weak ('institutional supports'). The Office of Climate Change Coordination (OCCC, est. 2007), situated within the Office of Natural Resources and Environmental Policy and Planning (ONEP) of the Ministry of Natural Resources and Environment (MNRE), is responsible for coordinating climate change mitigation and adaptation in Thailand (Limsoontorn 2010, Pipitsombat 2011). A "National Strategic Plan on Climate Change Management B.E. 2551-2555 (2008-2012)" (Government of Thailand 2008) and the more recent "10-Year Master Plan on Climate Change (2010-2019)" both focus on adaptation and mitigation measures (Government of Thailand, 2010). The adaptation focus in those documents is on agriculture, water, and disaster relief, with limited attention to the marine environment. Although 30 agencies and ministries participated in the central
Climate Change Coordinator under the OCCC, Lebel (2010) suggested that adaptation to climate change is still a recent policy initiative that has seen limited uptake by government departments. Our interviews with representatives of various government agencies, i.e., DNP, DoF, Department of Marine and Coastal Resources, Community Development Office, Ministry of Agriculture and Cooperatives, and the Navy, showed that there was a complete lack of 'knowledge' at the lower level about any policy initiatives or programs focused on climate change adaptation or even knowledge of 'climate change.' Even representatives of the recently (2002) established Department of Disaster Prevention and Mitigation (DDPM), which is mandated to plan for and implement community-based disaster mitigation strategies, seemed unclear about what the implications of climate change were for their department and about how they were planning for it. The DDPM has, however, established a network of early warning towers ('infrastructure') and communication systems for alerting communities of impending disasters after the tsunami.

Many climate change adaptation efforts in Thailand, Lebel (2010) suggested, are still limited to small, localized, or regional projects run by civil society groups. More recently several larger and longer-term (five year) coastal-focused climate change adaptation projects have emerged that bridge international donors with Thai civil society organizations and government agencies. These projects include the Rockefeller Foundation's Asian Cities Climate Change Resilience Network (ACCCRN), the Increase National Capacity for Climate Change Adaptation for Coastal Communities (INCA) program of the UNDP and Thai Red Cross Society, the Building Coastal Resilience to Reduce the Impact of Climate Change (BCR) initiative by Sustainable Development Foundation (SDF) and the International Union for the Conservation of Nature (IUCN), and the Building Coastal Community Resilience to Reduce Climate Impact (BCRCC) run by Raks Thai with CARE Deutschland (Tepa et al. 2011). These projects all focus on understanding climate change impacts and using participatory processes to adapt coastal cities and communities. However, they are still somewhat limited in scale, and none of them were, at the time of the study, actively engaged in work in the region under discussion.

\section{DISCUSSION AND RECOMMENDATIONS}

The analytical approach and methods we used to examine adaptive capacity were useful for understanding how communities are responding to the multiple social, environmental, and climatic changes that are occurring (Bennett et al. 2014a). Conceptually, we distinguished between adapting, reacting, and coping. Adapting refers to proactive and anticipatory planning of individual or collective actions based on knowledge or experience of past or anticipated future changes and that will likely result in no regrets or sustainable socialecological outcomes. Reacting, on the other hand, signifies an unplanned response to an event or change. Coping denotes passively accepting the consequences of a change or event and thus not changing behavior to alter outcomes. Our findings suggested that the study communities on the Andaman coast of Thailand are merely coping with ecological and fisheries declines and change such that many interview and survey participants did not know or felt that nothing could be done about fisheries declines. They are adapting unevenly to economic opportunity as 
evidenced by the differential dependencies on fisheries and other livelihoods, such as tourism and agriculture. And, they are being seriously buffeted by climate change, but have limited knowledge of its causes or consequences and little has been done to reduce its impacts, suggesting they are largely in reactive mode. What do these findings tell us about marine management and conservation, local development and climate change adaptation policies, programs and localized actions in Thailand, this region, and these communities? This analysis of adaptive capacity points to a number of interventions that might be taken at various scales for addressing shortfalls in adaptive capacity of coastal communities in this region of Thailand and elsewhere.

Moving communities beyond coping with environmental decline toward active rebuilding of depleted resources and eroded livelihoods and toward reducing or mitigating the effects of climate change and acidification requires a multifaceted approach. The conservation of marine resources and management of fisheries necessitates that the issues are addressed at multiple scales, i.e., from local to national to regional, simultaneously (BOBLME 2012, Pomeroy 2012). At the national level, this would require specific attention to the 'environmental policies and agencies,' particularly on the part of the DoF and DNP, 'participation in NRM and protected area decision making' and 'corruption' components of the adaptive capacity framework. Several actions are required by the DoF to increase the perceived legitimacy of the agency and its regulations and to improve compliance. An important initial step would be to ensure that regulations are appropriate to the ecological and social context and to monitor and adapt pre-existing legislations that are not functioning adequately. Improved participation in the development of regulations would ensure that they are contextually appropriate and more acceptable (Panjarat and Bennett 2012). Effective and equitable enforcement of regulations is a necessity that would require increased monitoring, control and surveillance, improved coordination among government agencies, increased physical and personnel capacity, and means to overcome industry-government corruption. Programs of outreach and education would increase fishers' knowledge about regulations and their ecological rationale. Establishing mechanisms to decrease fisheries conflicts could reduce the current "race to fish" (Grafton 2005). Moving from an open access regime toward a limited access common property regime might empower locals to develop environmental institutions through allowing for exclusion rights (Ostrom 1992). Adopting an integrated approach to coastal management could improve the overall health of the marine environment (MFF 2008, BOBLME 2012).

Significant improvements to the governance and management of NMPs are required to improve their acceptability and increase their effectiveness. Improving the perceived legitimacy of NMP and DNP governance structures would require increasing the transparency, accountability, inclusiveness, fairness, and adaptability of the system (Graham et al. 2003, Lockwood 2010), as well as reconsidering whether or not national park superintendents should be political appointments or hired because of their knowledge, experience, and skills (Prasertcharoensuk et al. 2010). Management capacity could be enhanced by addressing shortfalls in financing, infrastructure, skills, and leadership (Pomeroy et al. 2004). Initial planning processes could better incorporate the social and economic values of local communities (Sobel and Dahlgren 2004). Zoning of MPAs could reduce conflicts by providing multiple use areas for communities (Lunn and Dearden 2006). Outreach and education would improve knowledge of boundaries, regulations, the purpose of MPAs, and even the existence of MPAs (Leisher et al. 2012). Participation and relationships could be improved by establishing comanagement institutions. Consideration should be given to local development by establishing processes and capacity building programs to hire local people into management positions and by supporting the development of alternative livelihoods (Cattermoul et al. 2008, Bennett 2010).

At the local level, attention needs to be paid to the development of 'local environmental institutions and social norms,' 'resource monitoring, feedback and adaptation mechanisms,' and 'spaces for learning.' There are important roles for environmental policies and agencies and institutional support from ENGOs in the growth and maturation of these institutions (Sudtongkong and Webb 2008). Legislation and policies are needed to support local management and conservation initiatives (Johnson 1998), e.g., the Draft Community Forest Act (Government of Thailand 2007b) or the proposed Marine and Coastal Resource Management Act (DMCR 2012a,b). Environmental education and outreach by ENGOs could focus on effective means for conserving local resources, development of "conservation ethics," and documentation of local knowledge. Knowledge is lacking among ENGOs and local communities about the necessary inputs to create effective local MPAs (Bennett and Dearden 2012). Support is also needed for the (re)development (Jones et al. 2010) of local fisheries associations and cooperatives or other spaces for sharing and mechanisms for resource monitoring and the development of adaptive responses (Folke et al. 2003).

Although the factors aiding or interfering with livelihood adaptation were context specific, meaning generalized solutions are not possible and different things would need to be addressed in each community to facilitate adaptation to new livelihoods, some insights can be offered. There are several ways to improve the adaptability of households and individuals to economic and livelihood opportunities: build 'flexibility and diversity,' increase 'access to assets,' and improve 'governance and leadership.' Communities and households should be encouraged to maintain diverse livelihood portfolios, including the development of subsistence activities (Ellis and Allison 2004). Issues with land ownership, title, encroachment, or sales to outsiders have undermined diversification in many communities. Mechanisms need to be created to ensure locals are hired by businesspeople and community elites. The quality of local 'leadership and governance' structures could be addressed through capacitybuilding programs and networking between communities. The following assets also need to be considered: levels of 'education, ' 'relationships' with other communities, 'partnerships' with outside academics and private sector organizations, 'rights,' 'gender inequities,' 'sources of credit,' 'financial status,' and debts and community 'infrastructure.' There are important roles for NGOs and government agencies in facilitating and funding livelihood projects, advocating for local people's rights, and creating necessary policies to support local development. However, for outside 'institutional supports,' i.e., NGOs, governments, and community funds, to be more effective, 
development programs need to consider the local context, be longterm, address the needs of vulnerable groups, and engender local leadership.

Finally, improved adaptation to climate change would benefit from widespread programs of 'knowledge' mobilization and expanded 'institutional supports.' Improved 'knowledge of climate change' is needed in national, regional, and local governments and at community and household levels. Effective adaptation will require rapid and coordinated expansion of policies and programs for adaptation among Thai government agencies, both in terms of scope, with a renewed focus on the marine environment and coastal communities and in terms of scale. New projects should build on current coastal climate adaptation projects, i.e., INCA, BCR, and BCRCC, focus on proactive adaptations, and encourage low-cost and nature-based adaptations over costly infrastructure projects. Where necessary, infrastructure development would benefit from community decision-making processes facilitated by outsiders, incorporation of local knowledge, coordination between local and outside organizations, and accountability mechanisms. Disaster preparedness programs should be continued and expanded. Outside groups could facilitate participatory discussions about how to adapt communities, livelihoods, and households to the reality of climate change (Marshall et al. 2010, Bennett et al. $2014 b, c)$. Adaptation projects should consider the multiple stressors, e.g., economic, technical, social, and cultural factors that may be hindering adaptation and encourage the adoption of as many 'risk management' strategies as possible. At the household level, e.g., this includes diversifying livelihoods, limiting debt and saving money, participating in subsistence activities, e.g., household gardening and gleaning, reducing household costs, increasing levels of education, migrating for work and sending remittances, relying on more than one species, or planting more than one crop. The King of Thailand's philosophy of the Sufficiency Economy, with the three pillars of reasonableness, moderation, and immunity, also translated as risk management, and grounded by knowledge and morality, is a salient concept and a culturally appropriate place to continue discussions about managing risks and adapting to climate change in coastal communities (Sathirathai and Piboolsravut 2004). This philosophy has also seen significant uptake by various government agencies in Thailand and could, similarly, guide adaptation and risk management policies and practices.

\section{CONCLUSION}

Coastal communities worldwide are experiencing a broad array of environmental, climatic, and economic changes to which they must constantly adapt. We offer a distinctive, integrative perspective on these issues through the analysis of the adaptive capacity of seven island communities on the Andaman coast of Thailand to multiple stressors. We recommend different interventions for addressing the adaptive capacity gaps that communities may possess in relation to the various environmental, economic, and climatic changes that are occurring.

To improve adaptive capacity to climate change:

- Enhance knowledge of climate change at all levels of government and in local communities through extensive programs of outreach and education;
- Increase engagement in active risk management strategies at the household level;

- Build capacity at the community level for planning for current and future climate risks to households, infrastructure, and livelihoods;

- Expand institutional supports for climate change adaptation, including mainstreaming adaptation in policy and government and NGO conservation and development projects;

- Facilitate participatory adaptation planning processes at local and regional levels; and,

- Further develop disaster preparedness programs and infrastructure.

To improve adaptive capacity to environmental degradation and fisheries declines:

- Further enhance policies and processes to ensure local participation in protected areas decision making and empowerment of communities in natural resource management;

- Foster the development of local environmental institutions and social norms and resource monitoring, feedback and adaptation mechanisms; and,

- Promote spaces for sharing and learning, such as conservation groups and fishers' associations in local communities.

- Ameliorate deficiencies in the fisheries policies and management by the Department of Fisheries, including moving from the open access regime to a limited access common property regime;

- Enhance the management processes for National Marine Parks and tackle governance shortcomings within the Department of National Parks; and,

- Address issues with corruption in the Department of National Parks and the Department of Fisheries and ensure equitable enforcement of regulations.

To improve adaptive capacity to alternative livelihoods:

- On a site-by-site basis, focus on increasing community social and physical infrastructure and household livelihood assets, such as education, savings, land, tools, and skills;

- Encourage households and communities to maintain diverse economic and subsistence livelihood portfolios; 
- Cultivate the quality and capacity of community governance and leadership;

- Promote rights for and consideration of underprivileged groups, including women and stateless groups;

- Increase the effectiveness of development interventions from NGOs and governments; and,

- Facilitate positive relationships and long-term meaningful partnerships within communities, with other communities, and with outside organizations.

In our conceptual framework (Figure 1), we recognized that some factors, such as local governance and leadership, bonding and bridging social capital, rights and equity, gender relations, participation, levels of corruption, and occupational diversity, could facilitate or interfere with adaptation to multiple changes simultaneously. This makes these components of adaptive capacity virtually indispensable and thus credible starting places for facilitating community adaptation at the local scale. However, the other components of adaptive capacity are no less crucial to ensure functioning social-ecological systems in a changing climate. Conservation of the environment, e.g., coral reefs, mangroves, or fisheries, can also assist with mitigating against the impacts of climate change while also leading to beneficial livelihood outcomes.

In conclusion, we recognize that there are significant limitations placed on the adaptive capacity of communities by their connectedness to complex and uncertain environmental, economic, and socio-political systems at macroscales. Significant changes in the structure and functioning of coastal ecosystems and communities may be inevitable. Changes can also lead to positive transformations in communities and thus present themselves as opportunities. For opportunities to be embraced and the impacts of unwanted eventualities to be tempered or moved toward more desirable outcomes, it will increasingly require that proactive and mindful actions are taken to increase the adaptive capacity of communities at multiple scales from the national to the local.

Responses to this article can be read online at: http://www.ecologyandsociety.org/issues/responses. php/6315

\section{Acknowledgments:}

The results presented in this article are one aspect of the work of Project IMPAACT (http://projectimpaact.asia), a project of the Marine Protected Areas Research Group, Department of Geography, University of Victoria, Canada. Financial support for this project came from the Social Science and Human Research Council of Canada and the Bay of Bengal Large Marine Ecosystem Project. N. J. Bennett is a Trudeau Scholar, a SSHRC Scholar, a Fellow of the Protected Areas and Poverty Reduction Project, and a Fellow of the Centre for Global Studies. We recognize our Thai partners: the Department of National Parks, Niphon Phongsuwan of Phuket Marine Biological Centre, and researchers at Prince of Songkla University, and the invaluable contribution of three research assistants, Piyapat Nakornchai (Por), Alin Kadfak, and Jutathorn Pravattiyagul (Aice). A special thank you goes to the many participants who engaged with us. The map was created by Ole Heggen at the University of Victoria.

\section{LITERATURE CITED}

Adger, W. N. 2003. Social capital, collective action, and adaptation to climate change. Economic Geography 79 (4):387-404.

Adger, W. N. 2006. Vulnerability. Global Environmental Change 16(3):268-281. http://dx.doi.org/10.1016/j.gloenvcha.2006.02.006

Adger, W. N., N. W. Arnell, and E. L. Tompkins. 2005. Successful adaptation to climate change across scales. Global Environmental Change 15(2):77-86. http://dx.doi.org/10.1016/j.gloenvcha.2004.12.005

Adger, W. N, P. M. Kelly, A. Winkels, L. Q. Huy, and C. Locke. 2002. Migration, remittances, livelihood trajectories, and social resilience. AMBIO 31(4):358-366. http://dx.doi.org/10.1579/0044-7447-31.4.358

Adger, W. N., and K. Vincent. 2005. Uncertainty in adaptive capacity. Comptes Rendus Geosciences 337(4):399-410. http://dx. doi.org/10.1016/j.crte.2004.11.004

Armitage, D., and D. Johnson. 2006. Can resilience be reconciled with globalization and the increasingly complex conditions of resource degradation in Asian coastal regions? Ecology and Society 11(1): 2 [online] URL: http://www.ecologyandsociety.org/ vol11/iss 1/art2/

Armitage, D., and R. Plummer. 2011. Adaptive capacity and environmental governance. Springer, Berlin, Germany. http://dx. doi.org/10.1007/978-3-642-12194-4

Bailey, C., and C. Pomeroy. 1996. Resource dependency and development options in coastal Southeast Asia. Society and Natural Resources 9(2):191-199. http://dx.doi.org/10.1080/08941929609380964

Bay of Bengal Large Marine Ecosystem (BOBLME). 2012. Transboundary diagnostic analysis. Volume 1: issues, proximate and root causes. Bay of Bengal Large Marine Ecosystem Project, Phuket, Thailand. [online] URL: http://iwlearn.net/iwprojects/1252/reports/boblme-tda-volume-1/view

Bennett, N. J. 2010. Sustainable livelihoods from theory to conservation practice: an extended annotated bibliography of sustainable livelihoods approaches in protected areas community research. PAPR Working Paper Number 1. Protected Areas and Poverty Reduction Alliance (PAPR)/ Marine Protected Areas Research Group (MPARG), University of Victoria, Victoria, British Columbia, Canada.

Bennett, N. J. 2013. The capacity to adapt, conserve and thrive?: marine protected area communities and social-ecological change in coastal Thailand. Dissertation. University of Victoria, Victoria, British Columbia, Canada. [online] URL: https://dspace.library. uvic.ca:8443//handle/1828/4728 
Bennett, N. J., and P. Dearden. 2012. From outcomes to inputs: what is required to achieve the ecological and socio-economic potential of marine protected areas? MPARG Working Paper. Marine Protected Areas Research Group, University of Victoria, Victoria, British Columbia, Canada.

Bennett, N. J., and P. Dearden. 2014. Why local people do not support conservation: community perceptions of marine protected area livelihood impacts, governance and management in Thailand. Marine Policy 44:107-116. http://dx.doi. org/10.1016/j.marpol.2013.08.017

Bennett, N., P. Dearden, and A. M. Peredo. 2014a. Vulnerability to multiple stressors in coastal communities: a study of the Andaman Coast of Thailand. Climate and Development. http:// dx.doi.org/10.1080/17565529.2014.886993

Bennett, N. J., A. Kadfak, and P. Dearden. 2014b. Drawing the future together: adapting to change and creating the community and environment that we envision. Marine Protected Areas Research Group, University of Victoria, Victoria, British Columbia, Canada. [online] URL: http://mrnathanjbennett.files.wordpress. com/2012/08/bennett-kadfak-dearden-scenario-planning-report-1ban-tapae-yoi-final-2.pdf

Bennett, N. J., A. Kadfak, and P. Dearden. 2014c. The future we want: taking action in Ban Talae Nok for the community, the environment and climate change. Marine Protected Areas Research Group, University of Victoria, Victoria, British Columbia, Canada. [online] URL: http://mrnathanjbennett.files.wordpress. com/2012/08/bennett-kadfak-dearden-scenario-planning-report-2ban-talae-nok-final-2.pdf

Berman, R., C. Quinn, and J. Paavola. 2012. The role of institutions in the transformation of coping capacity to sustainable adaptive capacity. Environmental Development 2:86-100. http://dx.doi.org/10.1016/j.envdev.2012.03.017

Berkes, F., J. Colding, and C. Folke. 2003. Navigating socialecological systems: building resilience for complexity and change. Cambridge University Press, Cambridge, UK http://dx.doi. org/10.1017/CBO9780511541957

Berkes, F., and C. Folke. 1998. Linking social and ecological systems: management practices and social mechanisms for building resilience. Cambridge University Press, Cambridge, UK.

Blythe, J. 2013. Dynamics of fishers' responses to social-ecological change in coastal Mozambique: a resilience perspective. Dissertation. University of Victoria, Victoria, British Columbia, Canada. [online] URL: https://dspace.library.uvic.ca:8443// handle/1828/4860

Brierley, A. S., and M. J. Kingsford. 2009. Impacts of climate change on marine organisms and ecosystems. Current Biology 19 (14):R602-R614. http://dx.doi.org/10.1016/j.cub.2009.05.046

Brooks, N., W. N. Adger, and P. W. Kelly. 2005. The determinants of vulnerability and adaptive capacity at the national level and the implications for adaptation. Global Environmental Change 15 (2):151-163. http://dx.doi.org/10.1016/j.gloenvcha.2004.12.006

Bunce, M., S. Rosendo, and K. Brown. 2010. Perceptions of climate change, multiple stressors and livelihoods on marginal African coasts. Environment, Development and Sustainability 12 (3):407-440. http://dx.doi.org/10.1007/s10668-009-9203-6
Burton, I., R. W. Kates, and G. F. White. 1993. The environment as hazard. Second edition. Guilford, New York, New York, USA.

Carney, D. 1998. Sustainable rural livelihoods: what contribution can we make? Department of International Development, London, UK.

Carpenter, S. R., H. A. Mooney, J. Agard, D. Capistrano, R. S. DeFries, S. Díaz, T. Dietz, A. K. Duraiappah, A. Oteng-Yeboah, H. M. Pereira, C. Perrings, W. V. Reid, J. Sarukhan, R. J. Scholes, and A. Whyte. 2009. Science for managing ecosystem services: beyond the Millennium Ecosystem Assessment. Proceedings of the National Academy of Sciences 106(5):1305-1312. http://dx. doi.org/10.1073/pnas.0808772106

Cattermoul, B., P. Townsley, and J. Campbell. 2008. Sustainable livelihoods enhancement and diversification (SLED): a manual for practitioners. International Union for Conservation of Nature (IUCN), Gland, Switzerland and Colombo, Sri Lanka; Coral Reef Degradation in the Indian Ocean (CORDIO), Kalmar, Sweden; and International Coral Reef Action Network (ICRAN), Cambridge, UK. [online] URL: https://www.iucn.org/ knowledge/focus/previous focus topics/2009 marine/?uNewsID=2653

Charles, A. T. 2001. Sustainable fishery systems. Blackwell, Oxford, UK. http://dx.doi.org/10.1002/9780470698785

Cheung, C. P. S., B. P. Botengan, and W. R. D. Cruz. 2002. Marine protected areas in Southeast Asia. Association of Southeast Asian Nations (ASEAN), Regional Centre for Biodiversity Conservation, Los Baños, Philippines.

Cinner, J. E. 2011. Social-ecological traps in reef fisheries. Global Environmental Change 21(3):835-839. http://dx.doi.org/10.1016/ j.gloenvcha.2011.04.012

Cinner, J. E., M. M. P. B. Fuentes, and H. Randriahmahazo. 2009. Exploring social resilience in Madagascar's marine protected areas. Ecology and Society 14(1): 41. [online] URL: http://www. ecologyandsociety.org/vol14/iss1/art41/

Department of Marine and Coastal Resources (DMCR). $2012 a$. Marine and coastal resource management act (DRAFT). Department of Marine and Coastal Resources, Bangkok, Thailand.

Department of Marine and Coastal Resources (DMCR). $2012 b$. Proposed amendments to the marine and coastal resource management act (DRAFT). Department of Marine and Coastal Resources, Bangkok, Thailand.

Ellis, F. 2000. Rural livelihoods and diversity in developing countries. Oxford University Press, Oxford, UK.

Ellis, F., and E. Allison. 2004. Livelihood diversification and natural resource access. Food and Agriculture Organization of the United Nations (FAO), Rome, Italy. [online] URL: http://www. fao.org/sd/dim pe4/pe4 050502 en.htm

Engle, N. L. 2011. Adaptive capacity and its assessment. Global Environmental Change 21(2):647-656. http://dx.doi.org/10.1016/ j.gloenvcha.2011.01.019

Folke, C. 2006. Resilience: the emergence of a perspective for social-ecological systems analyses. Global Environmental Change 16(3):253-267. http://dx.doi.org/10.1016/j.gloenvcha.2006.04.002 
Folke, C., J. Colding, and F. Berkes. 2003. Synthesis: building resilience and adaptive capacity in social-ecological systems. Pages 352-387 in F. Berkes, J. Colding, and C. Folke, editors. Navigating social-ecological systems: building resilience for complexity and change. Cambridge University Press, Cambridge, UK. http://dx.doi.org/10.1017/CBO9780511541957.020

Füssel, H.-M. 2007a. Adaptation planning for climate change: concepts, assessment approaches, and key lessons. Sustainability Science 2(2):265-275. http://dx.doi.org/10.1007/s11625-007-0032$\mathrm{y}$

Füssel, H.-M. 2007b. Vulnerability: a generally applicable conceptual framework for climate change research. Global Environmental Change 17(2):155-167. http://dx.doi.org/10.1016/ j.gloenvcha.2006.05.002

Gallopín, G. C. 2006. Linkages between vulnerability, resilience, and adaptive capacity. Global Environmental Change 16 (3):293-303. http://dx.doi.org/10.1016/j.gloenvcha.2006.02.004

Government of Thailand. 2007a. Constitution of the kingdom of Thailand B.E. 2550 (2007). Government of Thailand, Bangkok, Thailand. [online] URL: http://english.constitutionalcourt.or.th/ index.php?option $=$ com docman\&Itemid $=4 \&$ lang $=$ en

Government of Thailand. 2007b. Draft community forest act. Government of Thailand, Bangkok, Thailand.

Government of Thailand. 2008. National strategic plan on climate change management B. E. 2551-2555 (2008-2012). Government of Thailand, Bangkok, Thailand.

Government of Thailand. 2010. 10-year master plan on climate change (2010-2019). Government of Thailand, Bangkok, Thailand.

Grafton, R. Q. 2005. Social capital and fisheries governance. Ocean and Coastal Management 48(9/10):753-766. http://dx.doi. org/10.1016/j.ocecoaman.2005.08.003

Graham, J., B. Amos, and T. Plumtree. 2003. Governance principles for protected areas in the $21^{\text {st }}$ century. Institute on Governance, Parks Canada, and Canadian International Development Agency (CIDA), Ottawa, Ontario, Canada. [online] URL: http://iog.ca/publications/governance-principles-for-protectedareas-in-the-21st-century/

Guinotte, J. M., and V. J. Fabry. 2008. Ocean acidification and its potential effects on marine ecosystems. Annals of the New York Academy of Sciences 1134(1):320-342. http://dx.doi.org/10.1196/ annals. 1439.013

Gunderson, L. H., and C. S. Holling. 2002. Panarchy: understanding transformations in human and natural systems. Island, Washington, D.C., USA.

Hagmann, J., and E. Chuma. 2002. Enhancing the adaptive capacity of the resource users in natural resource management. Agricultural Systems 73(1):23-39. http://dx.doi.org/10.1016/ S0308-521X(01)00098-1

Halpern, B. S., S. E. Lester, and J. B. Kellner. 2009. Spillover from marine reserves and the replenishment of fished stocks. Environmental Conservation 36(04):268-276. http://dx.doi. org/10.1017/S0376892910000032
Harley, C. D. G., A. R. Hughes, K. M. Hultgren, B. G. Miner, C. J. B. Sorte, C. S. Thornber, L. F. Rodriguez, L. Tomanek, and S. L. Williams. 2006. The impacts of climate change in coastal marine systems. Ecology Letters 9(2):228-241. http://dx.doi. org/10.1111/j.1461-0248.2005.00871.X

Hauzer, M., P. Dearden, and G. Murray. 2013. The effectiveness of community-based governance of small-scale fisheries, Ngazidja Island, Comoros. Marine Policy 38:346-354. http://dx. doi.org/10.1016/j.marpol.2012.06.012

Hill, M. 2013. Climate change and water governance. Springer, Dordrecht, the Netherlands. http://dx.doi.org/10.1007/978-94-007-5796-7

Hoegh-Guldberg, O., P. J. Mumby, A. J. Hooten, R. S. Steneck, P. Greenfield, E. Gomez, C. D. Harvell, P. F. Sale, A. J. Edwards, K. Caldeira, N. Knowlton, C. M. Eakin, R. Iglesias-Prieto, N. Muthiga, R. H. Bradbury, A. Dubi, and M. E. Hatziolos 2007. Coral reefs under rapid climate change and ocean acidification. Science 318(5857):1737-1742. http://dx.doi.org/10.1126/science.1152509

Holling, C. S. 1973. Resilience and stability of ecological systems. Annual Review of Ecology, Evolution, and Systematics 4(1):1-23. http://dx.doi.org/10.1146/annurev.es.04.110173.000245

Holling, C. S. 2001. Understanding the complexity of economic, ecological, and social systems. Ecosystems 4(5):390-405. http:// dx.doi.org/10.1007/s10021-001-0101-5

IBM. 2012. SPSS software: predictive analytics software and solutions. IBM Software, Armonk, New York, USA. [online] URL: http://www-01.ibm.com/software/analytics/spss/

International Union for the Conservation of Nature (IUCN). 2012. Declaration of common standpoint of small-scale fisher-folk network: small-scale fisher-folk, sustainable fishery management and marine and coastal resource management. International Union for the Conservation of Nature, Gland, Switzerland.

Johnson, C. 1998. Beyond community rights: small-scale fisheries and community-based management in southern Thailand. TDRI Quarterly Review 13(2):25-31. [online] URL: http://tdri.or.th/ archives/download/quarterly/text/j98 3.htm

Jones, E. V., T. S. Gray, and C. Umponstira. 2010. Small-scale fishing: perceptions and threats to conserving a livelihood in the province of Phang-Nga, Thailand. Environment Asia 3(1):1-7.

Juntaroshte, K. 2005. Country report for BOBLEME programme: Thailand. Department of Fishery Management, Kasetsart University, Bangkok, Thailand.

Kalikoski, D. C., P. Quevedo Neto, and T. Almudi. 2010. Building adaptive capacity to climate variability: the case of artisanal fisheries in the estuary of the Patos Lagoon, Brazil. Marine Policy 34(4):742-751. http://dx.doi.org/10.1016/j.marpol.2010.02.003

Knight, R., K. Watson, J. Dill, P. Moore, and K. Miller. 2010. A tool kit for protecting the environment and natural resources in Kuraburi, Phang Nga. International Union for Conservation of Nature (IUCN) Thailand Programme and IUCN Regional Environmental Law Programme, Asia, Bangkok, Thailand.

Lebel, L. 2010. Regional climate change adaptation knowledge platform Asia - scoping assessment for national implementation in Thailand. Unit for Social and Environmental Research, Chiang Mai University, Bangkok, Thailand. 
Leichenko, R., and K. O'Brien. 2008. Environmental change and globalization: double exposures. Oxford University Press, Oxford, UK.

Leisher, C., S. Mangubhai, S. Hess, H. Widodo, T. Soekirman, S. Tjoe, S. Wawiyai, S. N. Larsen, L. Rumetna, A. Halim, and M. Sanjayan. 2012. Measuring the benefits and costs of community education and outreach in marine protected areas. Marine Policy 36(5):1005-1011. http://dx.doi.org/10.1016/j.marpol.2012.02.022

Lemos, M. C., A. Agrawal, H. Eakin, D. R. Nelson, N. L. Engle, and O. Johns. 2013. Building adaptive capacity to climate change in less developed countries. Pages 437-457 in G. R. Asrar and J. W. Hurrell, editors. Climate science for serving society: research, modeling and prediction priorities. Springer, Dordrecht, the Netherlands. http://dx.doi.org/10.1007/978-94-007-6692-1 16

Lester, R. R., B. S. Halpern, L. Grorud-Colvert, J. Lubchenco, B. I. Ruttenberg, S. D. Gaines, S. Airamé, and S. S. Warner. 2009. Biological effects within no-take marine reserves: a global synthesis. Marine Ecology Progress Series 384:33-49. http://dx. doi.org/10.3354/meps08029

Limsoontorn, T. 2010. National strategy on climate change management: modeling and data application. Data Democracy Workshop on Climate Change, Geo-Informatics and Space Technology Development Agency (June 7-10, 2010). Office of Natural Resources and Environmental Policy and Planning, Ministry of Natural Resources and Environment of Thailand, Bangkok, Thailand. [online] URL: http://www.gistda.or.th/ gistda $\mathrm{n} / \mathrm{en} / \mathrm{index}$.php? option $=\mathrm{com}$ jevents $\&$ task $=$ icalrepeat. detail\&evid $=320 \&$ Itemid $=50 \&$ year $=2010 \&$ month $=06 \&$ day $=07 \&$ uid $=$ $\underline{\mathrm{e} 1376352 \mathrm{f} 1 \mathrm{~b} 6 \mathrm{cf} 948989834 \mathrm{a} 6771 \mathrm{f} 482}$

Lockwood, M. 2010. Good governance for terrestrial protected areas: a framework, principles and performance outcomes. Journal of Environmental Management 91(3):754-766. http://dx. doi.org/10.1016/j.jenvman.2009.10.005

Lunn, K. E., and P. Dearden. 2006. Fishers' needs in marine protected area zoning: a case study from Thailand. Coastal Management 34(2):183-198. http://dx.doi.org/10.1080/08920750$\underline{600567234}$

Marschke, M. J., and F. Berkes. 2006. Exploring strategies that build livelihood resilience: a case from Cambodia. Ecology and Society 11(1): 42. [online] URL: http://www.ecologyandsociety. org/vol11/iss1/art42/

Marshall, N. A., P. A. Marshall, J. Tamelander, D. Obura, D. Malleret-King, and J. E. Cinner. 2010. A framework for social adaptation to climate change: sustaining tropical coastal communities and industries. International Union for Conservation of Nature (IUCN), Gland, Switzerland. [online] URL: http:// www.iucn.org/about/work/programmes/marine/marine resources/ marine publications/?4943/A-Framework-for-Social-Adaptationto-Climate-Change

McCarthy, J. J., O. F. Canziani, N. A. Leary, D. J. Dokken, and K. S. White. 2001. IPCC third assessment report: climate change 2001: impacts, adaptation, and vulnerability. Cambridge University Press, Cambridge, UK. [online] URL: http://www. grida.no/publications/other/ipcc tar/?src=/climate/ipcc tar/wg2/ index.htm
McClanahan, T. R., J. E. Cinner, N. A. J. Graham, T. M. Daw, J. Maina, S. M. Stead, A. Wamukota, K. Brown, V. Venus, and N. V. C. Polunin. 2009. Identifying reefs of hope and hopeful actions: contextualizing environmental, ecological, and social parameters to respond effectively to climate change. Conservation Biology 23 (3):662-671. http://dx.doi.org/10.1111/j.1523-1739.2008.01154.x

Mangroves for the Future (MFF). 2008. Policy brief on governance and integrated coastal management. Mangroves for the Future, Bangkok, Thailand.

Ministry of Natural Resources and Environment (MNRE). 2010. Draft nomination document of the Andaman bioregion of Thailand for UNESCO World Heritage Nomination. Ministry of Natural Resources and Environment, Bangkok, Thailand.

Mustafa, D. 1998. Structural causes of vulnerability to flood hazard in Pakistan. Economic Geography 74(3):289-305. http:// dx.doi.org/10.2307/144378

O'Brien, K. L., and R. M. Leichenko. 2000. Double exposure: assessing the impacts of climate change within the context of economic globalization. Global Environmental Change 10 (3):221-232. http://dx.doi.org/10.1016/S0959-3780(00)00021-2

O'Garra, T. 2007. Supplementary livelihood options for Pacific Island communities: a review of experiences. Foundation of the Peoples of the South Pacific International, Suva, Fiji Islands. [online] URL: http://www.academia.edu/3743841/

Supplementary_Livelihood_Options_for_Pacific_Island_Communities a Review of Experiences

Ommer, R. E. 2007. Coasts under stress: restructuring and socialecological health. McGill-Queens University Press, Kingston, Ontario, Canada.

Ostrom, E. 1990. Governing the commons: the evolution of institutions for collective action. Cambridge University Press, Cambridge, UK. http://dx.doi.org/10.1017/CBO9780511807763

Ostrom, E. 1992. Crafting institutions for self-governing irrigation systems. Institute for Contemporary Studies, Richmond, California, USA.

Ostrom, E. 1999. Coping with tragedies of the commons. Annual Review of Political Science 2(1):493-535. http://dx.doi. org/10.1146/annurev.polisci.2.1.493

Panjarat, S. 2008. Sustainable fisheries in the Andaman Sea coast of Thailand. Division for Ocean Affairs and the Law of the Sea, Office of Legal Affairs, United Nations, New York, USA. [online] URL: http://www.un.org/depts/los/nippon/unnff programme home/ fellows_pages/fellows papers/panjarat 0708 thailand.pdf

Panjarat, S., and N. Bennett. 2012. Responses of fishers to a 25year seasonal closed measure on the Andaman Coast of Thailand. Project IMPAACT/Marine Protected Areas Research Group, University of Victoria, Victoria, British Columbia, Canada. [online] URL: http://dspace.library.uvic.ca:8080/bitstream/ handle/1828/4460/fishers-responses.pdf?sequence $=1$

Parry, M. L., O. F. Canziani, J. P. Palutikof, P. J. van der Linden, and C. E. Hanson. 2007. Climate Change 2007: impacts, adaptation and vulnerability: contribution of Working Group II to the fourth assessment report of the Intergovernmental Panel on Climate Change. Cambridge University Press, Cambridge, UK. 
[online] URL: https://www.ipcc.ch/publications and data/ publications ipcc_fourth_assessment_report_wg2_report_impacts adaptation and vulnerability.htm

Phongsuwan, N. 2011. Preliminary report of the effect of coral bleaching in 2010. Marine and Coastal Biology and Ecology Unit, Phuket Marine Biological Center, Phuket, Thailand.

Pipitsombat, N. 2011. Policy related to climate change in Thailand. Meeting of the Office of Natural Resources and Environmental Policy and Planning, Ministry of Natural Resources and Environment, Bangkok, Thailand. [online] URL: http://www. ostc.thaiembdc.org/atpac2011/Presentation_Ms_Nirawan.pdf

Pomeroy, R. S. 2012. Managing overcapacity in small-scale fisheries in Southeast Asia. Marine Policy 36(2):520-527. http:// dx.doi.org/10.1016/i.marpol.2011.10.002

Pomeroy, R. S., J. E. Parks, and L. M. Watson. 2004. How is your MPA doing?: a guidebook of natural and social indicators for evaluating marine protected area management effectiveness. International Union for Conservation of Nature (IUCN)/World Wildlife Fund (WWF), Gland, Switzerland. http://dx.doi. org/10.2305/IUCN.CH.2004.PAPS.1.en

Prasertcharoensuk, R., J. Shott, D. Sirisook Weston, and W. Ronarongpairee. 2010. Time for a sea change: a study of the effectiveness of biodiversity conservation measures and marine protected areas along Southern Thailand's Andaman Sea coastline. International Collective in Support of Fishworkers, Chennai, India. [online] URL: http://aquaticcommons.org/4227/

QSR International. 2012. NVivo 10 - qualitative research software. QSR Intrnational, Burlington, Massachusetts, USA. [online] URL: http://www.qsrinternational.com/products_nvivo.aspx

Resilience Alliance. 2010. Resilience. [online] URL: http://www. resalliance.org/576.php

SAS Institute. 2013. SAS statistical analysis software. SAS Institute, Cary, North Carolina, USA. [online] URL: http://www. sas.com/

Sathirathai, S., and P. Piboolsravut. 2004. Sufficiency economy and a healthy community. Paper presented at the 3rd International Union for Conservation of Nature (IUCN) World Conservation Congress, Bangkok, Thailand.

Scoones, I. 1998. Sustainable rural livelihoods: a framework for analysis. IDS Working Paper 72. Institute of Development Studies, Brighton, UK.

Sen, A. 1982. Poverty and famines: an essay on entitlement and deprivation. Oxford University Press, Oxford, UK.

Smit, B., and J. Wandel. 2006. Adaptation, adaptive capacity and vulnerability. Global Environmental Change 16(3):282-292. http:// dx.doi.org/10.1016/j.gloenvcha.2006.03.008

Smith, K. 2013. Environmental hazards: assessing risk and reducing disaster. Sixth Edition. Routledge, London, UK.

Smithers, J., and B. Smit. 1997. Human adaptation to climatic variability and change. Global Environmental Change 7 (2):129-146. http://dx.doi.org/10.1016/S0959-3780(97)00003-4
Sobel, J. A., and C. Dahlgren. 2004. Marine reserves: a guide to science, design, and use. Island, Washington, D.C., USA.

Southeast Asia Start Regional Centre (START). 2010. Preparation of climate change scenarios for climate change impact assessment in Thailand. Southeast Asia Start Regional Centre, Bangkok, Thailand.

Staber, U., and J. Sydow. 2002. Organizational adaptive capacity: a structuration perspective. Journal of Management Inquiry 11 (4):408-424. http://dx.doi.org/10.1177/1056492602238848

Sudtongkong, C., and E. L. Webb. 2008. Outcomes of state-vs. community-based mangrove management in southern Thailand. Ecology and Society 13(2): 27. [online] URL: http://www. ecologyandsociety.org/vol13/iss2/art27/

Swift, J. 1989. Why are rural people vulnerable to famine? IDS Bulletin 20(2):41-49. http://dx.doi.org/10.1111/j.1759-5436.1989. mp20002002.x

Tepa, C., Building Coastal Resilience to Reduce Climate Change Impact in Thailand and Indonesia (BCRCC), and Raks Thai. 2011. Findings on climate vulnerability and capacity assessment (CVCA) in Thailand. Building Coastal Resilience to Reduce Climate Change Impact in Thailand and Indonesia (BCRCC) Project Conference (December 8, 2011). BCRCC, Krabi, Thailand.

Tuler, S., J. Agyeman, P. P. da Silva, K. R. LoRusso, and R. Kay. 2008. Assessing vulnerabilities: integrating information about driving forces that affect risks and resilience in fishing communities. Human Ecology Review 15(2):171-184. [online] URL: http://www.humanecologyreview.org/152.htm

Turner, B. L., R. E. Kasperson, P. A. Matson, J. J. McCarthy, R. W. Corell, L. Christensen, N. Eckley, J. X. Kasperson, A. Luers, M. L. Martello, C. Polsky, A. Pulsipher, and A. Schiller. 2003. A framework for vulnerability analysis in sustainability science. Proceedings of the National Academy of Sciences 100 (14):8074-8079. http://dx.doi.org/10.1073/pnas.1231335100

Unnikrishnan, A. S., and D. Shankar. 2007. Are sea-level-rise trends along the coasts of the north Indian Ocean consistent with global estimates? Global and Planetary Change 57(3/4):301-307. http://dx.doi.org/10.1016/j.gloplacha.2006.11.029

Watts, M. J., and H. G. Bohle. 1993. The space of vulnerability: the causal structure of hunger and famine. Progress in Human Geography 17(1):43-67.

White, A., P. M. Aliño, and A. Meneses. 2006. Creating and managing marine protected areas in the Phillippines. Fisheries Improved for Sustainable Harvest Project, Coastal Conservation and Education Foundation, and University of the Phillippines Marine Science Institute, Cebu City, Phillipines.

World Bank. 2006. Thailand environment monitor 2006: marine and coastal resources. World Bank, Washington, D.C., USA. [online] URL: http://documents.worldbank.org/curated/ en/2006/12/8299902/thailand-environment-monitor-2006>

Yin, R. K. 2009. Case study research: design and methods. Fourth edition. SAGE, Thousand Oaks, California, USA. 
Bennett et al. 2014. The capacity to adapt?

Appendix A - Indicators and Methods Used to Analyze Different Components of the Adaptive Capacity Framework (I=Interview, $\mathrm{S}=$ Survey, KI=Key Informant, $\mathrm{SD}=$ Secondary Documents) $)^{1,2}$

\begin{tabular}{|c|c|c|c|}
\hline Category & Component & Indicator & Method $^{2}$ \\
\hline \multirow{23}{*}{$\begin{array}{l}\text { Flexibility and } \\
\text { Diversity }\end{array}$} & \multirow[t]{4}{*}{ Occupational mobility Attachment to occupation } & Level of occupational diversity throughout the year & $\mathrm{S}, \mathrm{I}, \mathrm{KI}$ \\
\hline & & Number of employment changes in last 10 years & $\mathrm{S}$ \\
\hline & & Response to hypothetical change in primary livelihood - What would you do if unable to make a living? & $\mathrm{S}$ \\
\hline & & Livelihood narratives and values & I \\
\hline & \multirow{7}{*}{$\begin{array}{l}\text { Occupational multiplicity Livelihood and income } \\
\text { diversity }\end{array}$} & Number of different types of marine resource utilized for income purposes & S \\
\hline & & Number of different gear types utilized & $\mathrm{S}$ \\
\hline & & Number of different livelihoods in a household. & $\mathrm{S}$ \\
\hline & & Diversity of livelihood opportunities throughout the year (seasonality) & KI \\
\hline & & Diversity of livelihood opportunities available to men versus women & $\mathrm{S}, \mathrm{I}$ \\
\hline & & Average income in rainy versus dry season & $\mathrm{S}$ \\
\hline & & Average income in rainy versus dry season (by Gender) & $\mathrm{S}$ \\
\hline & \multirow{6}{*}{ Dependence on natural resources (fisheries) } & Percentage of primary livelihoods in community that are fisheries related & $\mathrm{S}, \mathrm{I}$ \\
\hline & & Relative importance of fisheries as a secondary livelihood & $\mathrm{S}$ \\
\hline & & Relative importance of subsistence marine livelihood activities (\# of items used) & $\mathrm{S}$ \\
\hline & & Contribution (\%) of fisheries livelihoods to household income & $\mathrm{S}$ \\
\hline & & Number of nights a week that house eats seafood (food security) & $\mathrm{S}$ \\
\hline & & Relative importance of tourism to community and of natural resources to tourism & I \\
\hline & \multirow[t]{2}{*}{ Perception of risk } & Perception of how much of a risk climate change poses to the community or to livelihoods (1-5 ordinal ranking) & $\mathrm{I}, \mathrm{S}$ \\
\hline & & $\begin{array}{l}\text { Ranking the order of a number of different changes in terms of risks to community - How much impact do change events } \\
\text { have on your household or livelihoods (1-5 ordinal ranking) }\end{array}$ & $\mathrm{S}$ \\
\hline & \multirow[t]{4}{*}{ Place attachment } & Willingness to re-locate for livelihood purposes & $\mathrm{S}$ \\
\hline & & Length of time living in the area & $\mathrm{S}$ \\
\hline & & Origin of interviewee & $\mathrm{S}$ \\
\hline & & Family members living away from area & $\mathrm{S}$ \\
\hline \multirow{14}{*}{$\begin{array}{l}\text { Capacity to } \\
\text { Organize }\end{array}$} & \multirow[t]{6}{*}{ Bonding social capital and networks } & Level of participation in community organizations & $\mathrm{S}, \mathrm{I}$ \\
\hline & & Level of support from family and friends (inside and outside community) & $\mathrm{S}$ \\
\hline & & Ranking and rating of importance of community organizations & $\mathrm{S}$ \\
\hline & & Local hiring practices & I \\
\hline & & Relationships with local middlemen in the community (benevolence) & I \\
\hline & & History of collective action & I \\
\hline & \multirow{2}{*}{ Gender relations } & Proportion of women in leadership roles & I \\
\hline & & Women have equal access to and control over critical livelihood resources & $\mathrm{S}$ \\
\hline & \multirow{6}{*}{$\begin{array}{l}\text { Participation in community, regional, and } \\
\text { protected area decision making }\end{array}$} & How are people involved with community organizations? - number ways and nature of involvement & S \\
\hline & & How involved people are in community decision making (ordinal score ranking 1-5) & $\mathrm{S}$ \\
\hline & & How involved people are in regional decision making (ordinal score ranking 1-5) & $\mathrm{S}$ \\
\hline & & How involved are people in the community in protected area management (ordinal score ranking 1-5) & S, I \\
\hline & & How involved are people in management of natural resources in the area? (ordinal score ranking 1-5) & $\mathrm{S}$ \\
\hline & & DNP policies for participation and presence of active programs of outreach and engagement to communities and groups & $\mathrm{I}, \mathrm{SD}$ \\
\hline
\end{tabular}

${ }^{1}$ Citation: Bennett, N.J., Dearden, P., Murray, G. and Kadfak, A. 2014. The capacity to adapt?: Communities in a changing climate, environment and economy on the northern Andaman Coast of Thailand. Ecology \& Society. Online.

${ }^{2}$ Corresponding research instruments can be found in Bennett, N. J. 2013. The capacity to adapt, conserve and thrive?: marine protected area communities and socialecological change in coastal Thailand. University of Victoria, Victoria, BC. [online] URL: https://dspace.library.uvic.ca:8443//handle/1828/4728 
Bennett et al. 2014. The capacity to adapt? 2

\begin{tabular}{|c|c|c|c|}
\hline Category & Component & Indicator & Method $^{2}$ \\
\hline & \multirow[t]{5}{*}{ Local environmental institutions and social norms } & $\begin{array}{l}\text { Qualitative exploration of rules, practices, and norms that the community uses to conserve natural resources (e.g., habitats } \\
\text { protected, } 5 \text { types of restrictions, qualitative exploration of rules and regs) }\end{array}$ & KI, I, S \\
\hline & & Presence of conservation ethic - qualitative judgement & $\mathrm{I}$ \\
\hline & & Qualitative exploration of relative community knowledge of the rules and norms & $\mathrm{I}, \mathrm{KI}$ \\
\hline & & Qualitative exploration of how and whether regulations are enforced & $\mathrm{I}, \mathrm{KI}$ \\
\hline & & Community trust and perceptions of justness and fairness in resource allocation & $\mathrm{S}, \mathrm{I}$ \\
\hline & \multirow[t]{10}{*}{ Environmental policies and agencies } & Knowledge of national park - existence, names, rules and regulations, purpose & $\mathrm{S}, \mathrm{I}$ \\
\hline & & Perceptions of national park management and governance & $\mathrm{S}, \mathrm{I}$ \\
\hline & & Following of rules created by the DNP & I \\
\hline & & Perceptions of fisheries management and agencies & $\mathrm{I}$ \\
\hline & & Following of rules created by fisheries & $\mathrm{I}$ \\
\hline & & Perceptions of DMCR management and agencies & I \\
\hline & & Enforcement of rules and regulations & $\mathrm{I}$ \\
\hline & & $\begin{array}{l}\text { Cooperation and trust between various government agencies - fisheries department, national parks department, DMCR, } \\
\text { marine police, etc }\end{array}$ & $\mathrm{I}, \mathrm{SD}$ \\
\hline & & Legislation to support local management & $\mathrm{I}, \mathrm{SD}$ \\
\hline & & Harmonization of policies with actions at various scales & $\mathrm{I}, \mathrm{SD}$ \\
\hline & \multirow[t]{3}{*}{ Governance and leadership } & Perceptions of local leaderships role in overcoming problems & $\mathrm{S}$ \\
\hline & & Qualitative descriptions of the community leadership and governance processes & $\mathrm{I}, \mathrm{KI}$ \\
\hline & & Perceptions of local leadership and governance & I, S \\
\hline & \multirow[t]{3}{*}{ Levels of corruption } & Perceptions of level of corruption in community, protected area and regional governments & $\mathrm{I}, \mathrm{SD}$ \\
\hline & & Ranking of impact of corruption as change event on household livelihoods & $\mathrm{S}$ \\
\hline & & National corruption index & SD \\
\hline & \multirow[t]{2}{*}{ Active risk management } & $\begin{array}{l}\text { Are people managing risk by planning for and investing in the future (Do people have reserves of food, savings, or protect } \\
\text { assets from hazards?) }\end{array}$ & KI, S \\
\hline & & How community plans for adaptation and plans for risks & KI, I \\
\hline & \multirow{3}{*}{ Migration } & Whether born in the community or region & $\mathrm{S}$ \\
\hline & & Number of years living in the community (-AC) & $\mathrm{S}$ \\
\hline & & Children living and working away from the community $(+\mathrm{AC})$ & $\mathrm{S}$ \\
\hline \multirow{20}{*}{$\begin{array}{l}\text { Learning and } \\
\text { Knowledge }\end{array}$} & \multirow{4}{*}{$\begin{array}{l}\text { Resource monitoring, feedback, and adaptation } \\
\text { mechanisms }\end{array}$} & Qualitative exploration of rules, practices, and norms that the community uses to conserve natural resources & $\mathrm{I}, \mathrm{KI}$ \\
\hline & & Exploration of how rules have changed in the past in response to perceived environmental changes (flexibility) & $\mathrm{I}, \mathrm{KI}$ \\
\hline & & Qualitative exploration of engagement with knowledge from past change events into current thinking and practice & $\mathrm{I}, \mathrm{KI}$ \\
\hline & & Presence or absence of adaptive management in MPA management & $\mathrm{I}, \mathrm{SD}$ \\
\hline & \multirow[t]{5}{*}{ Knowledge and experience of climate change } & Experience of climate change related changes (e.g., storms, etc...) & $\mathrm{I}, \mathrm{PV}, \mathrm{S}$ \\
\hline & & Understanding and knowledge of the present and potential future impacts of climate change & $\mathrm{S}$ \\
\hline & & Number of sources of climate change information & $\mathrm{S}$ \\
\hline & & Regional-community extension workers and government understand climate risks & I \\
\hline & & Access to climate change information at regional and local level & $\mathrm{I}, \mathrm{S}$ \\
\hline & \multirow[t]{3}{*}{ Spaces for learning } & Presence of active programs of outreach, education, and engagement with communities & $\mathrm{S}, \mathrm{KI}$ \\
\hline & & Qualitative discussion of formal and informal spaces for anticipatory learning and action & $\mathrm{I}, \mathrm{KI}$ \\
\hline & & Involvement of communities in NRM - national parks and fisheries & S, I \\
\hline & \multirow[t]{3}{*}{ Diversity of knowledges for NRM } & Level of incorporation of diverse knowledges in NRM and conservation & $\mathrm{I}, \mathrm{SD}$ \\
\hline & & Presence and strength of traditional knowledge & $\mathrm{I}, \mathrm{SD}$ \\
\hline & & Past or active programs of documentation of Traditional Knowledge & $\mathrm{I}, \mathrm{SD}$ \\
\hline & \multirow{2}{*}{$\begin{array}{l}\text { Capacity to anticipate change and develop } \\
\text { response strategies }\end{array}$} & Identification of factors that cause change to number of fish in the sea & $\mathrm{S}, \mathrm{I}$ \\
\hline & & Identification of actions that could help to conserve resources or increase the number of fish in the sea & $\mathrm{S}, \mathrm{I}$ \\
\hline & \multirow[t]{3}{*}{ Recognition of causality and human agency } & Naming of factors that cause declines in marine resources. & $\mathrm{S}, \mathrm{I}$ \\
\hline & & Naming of human factors that cause declines in marine resources & $\mathrm{S}, \mathrm{I}$ \\
\hline & & Naming of interventions for conserving resources & $\mathrm{S}, \mathrm{I}$ \\
\hline \multirow[t]{2}{*}{ Access to Assets } & \multirow[t]{2}{*}{ Material assets } & Household construction materials & $\mathrm{S}$ \\
\hline & & Proximity of house to beach & $\mathrm{S}$ \\
\hline
\end{tabular}


Bennett et al. 2014. The capacity to adapt? 3

\begin{tabular}{|c|c|c|c|}
\hline Category & Component & Indicator & Method $^{2}$ \\
\hline \multirow{44}{*}{ Category } & & Number and quality of household appliances & $\mathrm{S}$ \\
\hline & & Number of boats & $\mathrm{S}$ \\
\hline & & Number of land vehicles & $\mathrm{S}$ \\
\hline & & Diversity of fishing gears & $\mathrm{S}$ \\
\hline & & Ownership of house and land for house & $\mathrm{S}$ \\
\hline & & Ownership of land and number of rai - suitability of land & $\mathrm{S}$ \\
\hline & \multirow{3}{*}{ Infrastructure } & Presence of 20 infrastructure items in community & KI \\
\hline & & Presence of infrastructure for disaster prevention & I \\
\hline & & Presence of tourism related infrastructures & $\mathrm{I}, \mathrm{KI}$ \\
\hline & \multirow[t]{2}{*}{ Levels of education } & Levels of formal education & $\mathrm{S}$ \\
\hline & & Family members attending school away from the area & $\mathrm{S}$ \\
\hline & \multirow[t]{11}{*}{ Financial status and access to sources of credit } & Relative income-poverty level & $\mathrm{S}$ \\
\hline & & Perception of income versus household expenses & $\mathrm{S}$ \\
\hline & & Qualitative exploration of economic costs - household and livelihood & I \\
\hline & & Balance of debt to income & $\mathrm{S}$ \\
\hline & & Presence or absence of financial savings & $\mathrm{S}$ \\
\hline & & Balance of debt to savings & $\mathrm{S}$ \\
\hline & & Access to sources of credit - number of items & $\mathrm{S}$ \\
\hline & & Remittances from family members - amount, remittance to household income ratio & $\mathrm{S}$ \\
\hline & & Comprehensive wealth ranking & $\mathrm{S}$ \\
\hline & & Number of laborers & $\mathrm{S}$ \\
\hline & & Number of dependents in the household & $\mathrm{S}$ \\
\hline & \multirow[t]{5}{*}{ Bridging social capital } & Partnerships with outside academic organizations or NGOs on local development projects & KI \\
\hline & & Levels of participation in organizations from outside the community & $\mathrm{S}$ \\
\hline & & Relative importance of organizations from outside the community in overcoming challenges & $\mathrm{S}$ \\
\hline & & Qualitative explorations of conflict between communities and groups & I \\
\hline & & Presence of social and economic "safety nets" in case of disaster & $\mathrm{I}, \mathrm{KI}$ \\
\hline & \multirow[t]{5}{*}{ Institutional support } & Presence of local and regional institutions that are involved in facilitating adaptation & $\mathrm{I}, \mathrm{SD}$ \\
\hline & & Government organizations with mandates to incorporate climate change considerations & $\mathrm{I}, \mathrm{SD}$ \\
\hline & & Presence of policies, programs, and plans for climate change adaptation & SD \\
\hline & & Involvement of civil society in planning and implementation of CC adaptation & I, SD \\
\hline & & Financial support for adaptation programs for building AC (community and industry) & $\mathrm{I}, \mathrm{SD}$ \\
\hline & \multirow[t]{4}{*}{ Natural capital } & Relative diversity of natural resource base and habitats (utilized) & $\mathrm{I}, \mathrm{S}$ \\
\hline & & Health of the marine ecosystem - fish in the sea & $\mathrm{S}, \mathrm{I}$ \\
\hline & & Suitability of the site for tourism & KI \\
\hline & & Access to and control over critical livelihood resources (rules, perceptions, actual?) & $\mathrm{I}, \mathrm{S}$ \\
\hline & \multirow[t]{8}{*}{ Equity and rights } & Perceptions of equity in access to resources & $\mathrm{S}$ \\
\hline & & Equity in sharing of benefits from livelihoods & $\mathrm{S}$ \\
\hline & & Equitable distribution of wealth among various groups & $\mathrm{S}$ \\
\hline & & Participation of most vulnerable in planning processes & $\mathrm{I}, \mathrm{S}$ \\
\hline & & Perceptions of equity for women in access to resources & $\mathrm{S}$ \\
\hline & & Thai ID numbers and the rights associated with these & $\mathrm{I}$ \\
\hline & & Comprehensive equity ranking & $\mathrm{S}$ \\
\hline & & Relative equity in wealth within the community (comprehensive ranking) & $\mathrm{S}$ \\
\hline
\end{tabular}

